\title{
Avoided Mortality Associated with Improved Air Quality from an Increase in Renewable Energy in the Spanish Transport Sector: Use of Biofuels and the Adoption of the Electric Car
}

\author{
Ana R. Gamarra ${ }^{1,2, *(D)}$, Yolanda Lechón ${ }^{1}\left(\mathbb{D}\right.$, Marta G. Vivanco ${ }^{3}$, Mark Richard Theobald ${ }^{3}\left(\mathbb{D}\right.$, Carmen Lago $^{1}$, \\ Eugenio Sánchez $^{4}\left(\mathbb{D}\right.$, José Luis Santiago ${ }^{3} \mathbb{D}$, Juan Luis Garrido ${ }^{3}$, Fernando Martín ${ }^{3}$ (D), Victoria Gil ${ }^{3}(\mathbb{D}$ \\ and Alejandro Rodríguez-Sánchez ${ }^{3}$ (D)
}

Citation: Gamarra, A.R.; Lechón, Y.; Vivanco, M.G.; Theobald, M.R.; Lago, C.; Sánchez, E.; Santiago, J.L.; Garrido, J.L.; Martín, F.; Gil, V.; et al. Avoided Mortality Associated with Improved Air Quality from an Increase in Renewable Energy in the Spanish Transport Sector: Use of Biofuels and the Adoption of the Electric Car. Atmosphere 2021, 12, 1603. https:// doi.org/10.3390/atmos12121603

Academic Editor: Daniele Contini

Received: 27 October 2021

Accepted: 29 November 2021

Published: 30 November 2021

Publisher's Note: MDPI stays neutral with regard to jurisdictional claims in published maps and institutional affiliations.

Copyright: (c) 2021 by the authors. Licensee MDPI, Basel, Switzerland. This article is an open access article distributed under the terms and conditions of the Creative Commons Attribution (CC BY) license (https:/ / creativecommons.org/licenses/by/ $4.0 /)$.
1 CIEMAT, Energy Systems Analysis Unit, Energy Department, Av. Complutense, 40, 28040 Madrid, Spain; yolanda.lechon@ciemat.es (Y.L.); carmen.lago@ciemat.es (C.L.)

2 Universidad Politécnica de Madrid, Av. José Gutierrez Abascal, 2, 28006 Madrid, Spain

3 CIEMAT, Atmospheric Pollution Division, Av. Complutense, 40, 28040 Madrid, Spain; m.garcia@ciemat.es (M.G.V.); mark.theobald@ciemat.es (M.R.T.); jl.santiago@ciemat.es (J.L.S.); juanluis.garrido@ciemat.es (J.L.G.); fernando.martin@ciemat.es (F.M.); VictoriaE.Gil@ciemat.es (V.G.); Alejandro.Rodriguez@ciemat.es (A.R.-S.)

4 CIEMAT, Application and Computer Systems Development Unit, Department of Technology, Av. Complutense, 40, 28040 Madrid, Spain; eugenio.sanchez@ciemat.es

* Correspondence: anarosa.gamarra@ciemat.es

Abstract: This paper assesses the health impact, in terms of the reduction of premature deaths associated with changes in air pollutant exposure, resulting from double-aim strategies for reducing emissions of greenhouse gases and air pollutants from the transport sector for the year 2030 in Spain. The impact on air quality of selected measures for reducing emissions from the transport sector (increased penetration of biofuel and electric car use) was assessed by air quality modeling. The estimation of population exposure to $\mathrm{NO}_{2}$, particulate matter (PM) and $\mathrm{O}_{3}$ allows for estimation of associated mortality and external costs in comparison with the baseline scenario with no measures. The results show that the penetration of the electric vehicle provided the largest benefits, even when the emissions due to the additional electricity demand were considered.

Keywords: health impact assessment; air pollution modeling; external costs; renewable mobility; environmental co-benefits

\section{Introduction}

Transportation allows the movement of people and products as well as connection between cities, countries and economies around the world, fostering economic growth and jobs. However, transport remains one of the main sources of environmental impacts in Europe, accounting for more than a fifth of greenhouse gas emissions (GHG), most of which are generated by road transport (71.7\%) [1]. In addition to emissions of $\mathrm{CO}_{2}$, road traffic is responsible for emissions of other pollutants that affect human health. Road transport, and specifically internal combustion engine vehicles, releases more than 40 pollutants directly into the air, including carbon dioxide $\left(\mathrm{CO}_{2}\right)$, sulfur dioxide $\left(\mathrm{SO}_{2}\right)$, oxides of nitrogen (NOx), particulate matter of various size fractions $\left(\mathrm{PM}_{10}, \mathrm{PM}_{2.5}\right.$ and ultrafine) and a suite of non-methane volatile organic compounds (NMVOCs) [2].

Faced with the urgent need to move towards a decarbonized society, the impacts associated with the deployment of national strategies must ensure co-benefits that achieve both environmental and social well-being. The development of coherent policies between issues is one pathway to maximize the highest potential well-being for the coming decades. In Spain, the integrated National Energy and Climate Plan (NECP) [3] and the first National Air Pollution Control Program (NAPCP) [4] offer a framework for the development of 
strategies and measures to be implemented by 2030. There are synergies between air pollution control and climate change mitigation since they share common emission sources and, to a large extent, solutions, while the majority of air pollutants also impact the climate to some degree (with both negative and positive effects). Significant economic impacts, in terms of social costs associated with mortality and morbidity due to air pollution, have been estimated [5-10], as well as the investment that is needed to mitigate and adapt to climate change [11-14]. Climate change and air pollution reduction strategies have relevant co-benefits in terms of costs [15]; however, adverse side-effects of mitigation have also been identified [14].

Methods for analyzing the co-benefits of carbon emission reduction policies and scenarios, including a range of different benefits, in Europe [16,17] and around the world [18-21], have been developed in the scientific literature during the last two decades. While benefits associated with carbon emission mitigation policies are frequently assessed on the regional or global scale over long timescales, studies on the health impacts of air pollution strategies are normally focused at the national, local or city level over a shorter time scale [22-25]. Research on co-benefits at the national level has been developed in recent years [26-29], addressing key sectors such as the transition of the power, industrial and transport sectors around the world [30-32]. At the city and urban level there have been studies on co-benefits as well [33,34].

Regarding policies on transportation, several measures have been proposed by governments around the world on the pathway to decarbonization. Among these, the most popular measures proposed for Climate Action [35] are: (1) electrification, (2) low-carbon fuels and energy vectors, (3) improved design, operations and planning of transport systems, (4) mode shift and demand management and (5) innovation and up-scaling. In recent years, progress has been made with policies for the increase of use of natural gas powered and electric vehicles (EV), as well as bio-fuels and advanced fuels and the substitution of public bus fleets to provide a clean network for the transportation of passengers. Other proposals include the development of urban infrastructures (increasing pedestrian areas and transport by rail and investing in tram and cycle networks). These would result in reduced emissions of traffic-related $\mathrm{CO}_{2}$ as well as other air pollutants from road transport. A range of measures at the national level have been proposed by the Spanish government for the transport sector as part of packages or sectorial measures for the year 2030, including measures for improving air quality in cities, such as the development of Zero Emission Areas (increasing control and regulation over users) or parking areas in suburbs around cities. Previous studies have assessed the impact on air quality [36] and health of the implementation of all the measures proposed in the NAPCP combined [37].

The objective of this study is to assess the health impact and associated external costs of selected measures for the decarbonization of the transport sector in Spain, namely the blending of biofuels and the use of electric vehicles, by estimating health impacts and the associated external costs.

\section{Materials and Methods}

Air quality modeling has been used in combination with health impact assessment (HIA) in order to estimate the effect on mortality associated with selected strategies for increasing renewable energy in the transport sector.

\subsection{Description of Measures and Scenarios}

In 2009, the European Parliament and Council adopted the 'Renewable Energy Directive' (RED), which includes an ambitious policy target for the transport sector: a 10\% overall target for the share of energy from renewable sources in 2020. To achieve this, the directive establishes objectives for GHG reductions in order to ensure that the renewable quota is linked to climate change mitigation and sustainability criteria, considering the penetration of several fuels, such as biofuels and other renewable sources. In June 2018, the new Renewable Energy Directive for the period 2021-2030 (named REDII) was adopted [38], 
establishing a new share of renewable energy within the final consumption of energy in the transport sector. Recently, in July 2021, REDII was proposed for amendment [39] (PA-REDII). In that proposal, the criterion is based on a reduction in GHG intensity instead of on the contribution to the final demand. Thus, the amount of renewable fuels and renewable electricity supplied to the transport sector should lead to a reduction in GHG intensity of at least $13 \%$ by 2030 . Also, the PA-REDII introduces a mechanism to promote $\mathrm{EV}$, for which operators supplying renewable power to EV via public charging stations would receive credits for trade with fuel suppliers.

In consequence, the EU members' governments will have to design and adjust their plans accordingly. This is the case for the Spanish NECP, which foresees a share of renewable energy in transport in Spain of 28\% in 2030 (much higher than the number given by the directive). To achieve this, the contribution of biofuels from food and feed crops and from advanced biofuels will be $6.8 \%$ and $3.7 \%$, respectively, and five million electric vehicles (EV) will be on the roads.

In this study, we analyze four scenarios for the year 2030: two for biofuels and two for electric cars. The scenarios were designed to estimate the maximum possible benefit with regards to improved air quality, health impacts and greenhouse gas emissions. The two scenarios for biofuels assess an ambitious increase in biofuel blending in fuels for petrol vehicles only (BioEt) and all petrol and diesel vehicles (Biof), respectively. The other two scenarios consider the total substitution of the current fleet of fossil-fuel passenger cars (except the current hybrid fleet) by EV. One of these scenarios (EC) does not take into account the increased electricity consumption while the other (EC-E) does, as well as taking into account the increase in the renewable electricity generation by 2030 .

Table 1 provides a brief description of the selected scenarios and measures. The following sections, Sections 2.1.1 and 2.1.2, describe the measures selected, the assumptions made and the resulting scenarios.

Table 1. Description of the assessed scenarios and measures.

\begin{tabular}{|c|c|c|}
\hline Scenario & & Description of Measures \\
\hline \multirow{3}{*}{ Biofuels } & BioEt & $\begin{array}{l}\text { Renovation of petrol passenger fleet (cars and motorcycles) to flexible-fuel vehicles and the use of E85 } \\
\text { petrol }(85 \% \text { bioethanol/15\% petrol mixture) by the year } 2030 \text {. Other petrol vehicles: increase bioethanol } \\
\text { content from E5 (5\%) to E10 }(10 \%) \text {. }\end{array}$ \\
\hline & & Increased biofuel use by two combined measures: \\
\hline & Biof & $\begin{array}{l}\text { - Increased bioethanol use in petrol vehicles (Same as Scenario BioEt) } \\
\text { - Increased biodiesel use: Use of biodiesel (B20; 20\% biodiesel) in diesel vehicles (except } \\
\text { motorcycles). }\end{array}$ \\
\hline \multirow[b]{2}{*}{ Electric car } & $\mathrm{EC}$ & $\begin{array}{l}\text { Promotion of electromobility: Current fleet of passenger cars (except hybrids) substituted by electric cars. } \\
\text { The scenario does not include the additional electricity generation }\end{array}$ \\
\hline & EC-E & $\begin{array}{l}\text { Promotion of electromobility: Current fleet of passenger cars (except hybrids) replaced by electric cars. } \\
\text { The scenario includes the additional electricity generation, considering the share of technologies in the } \\
\text { power mix for } 2030 \text { (considered in NECP) and the change in the absolute production by renewables and } \\
\text { fossil technologies. }\end{array}$ \\
\hline
\end{tabular}

\subsubsection{Increase in Biofuel Blending}

Biofuels are liquid fuels for transport produced from biomass. Biofuels are classified into four generations [40]. First generation biofuels use food crops as biomass feedstock, although several of them compete with global food needs. Second generation biofuels use non-food crops, although the cost-effectiveness is debated. Third and fourth generation biofuels are still in development and use microbiological methods, biotechnology and genetics.

Biofuels have been promoted in many countries through the establishment of mandatory blends and use targets. A mandatory blend refers to the proportion of biofuel that a fuel has to contain to enter the consumer market, expressed as a percentage. The second 
type of mandatory mechanism refers to target levels of biofuel use with respect to overall transportation fuels. These two mechanisms are not exclusive, since the use of mandatory blends is one of the policies that can be used to meet use targets.

In the European market, a substantial share of biofuels comes from the blending of biodiesel in diesel and of bioethanol in petrol. Current fuel standards are $7 \%$ and $20 \%$ by volume of fatty acid methyl esters (FAME, the most common type of biodiesel; B7 and B20) for diesel and 5\%,10\% and 85\% by volume of ethanol for petrol (E5, E10 and E85). In Spain, the Royal Decree 1085/2015 for biofuel promotion and the Royal Decree 205/2021 [41] establish the objectives for the sale or consumption of biofuels in transportation, according to REDII.

In this paper, two scenarios of increased biofuel use have been analyzed; one of them (BioEt) assesses the individual impact of the use of E85 biofuel in petrol cars and motorcycles and the use of E10 biofuel in all other petrol vehicles. The other (Biof) assesses the impact of the increase in use of both bioethanol and biodiesel. This second scenario combines the increase in biofuel use for both petrol and diesel vehicles. The scenario includes the use of E85 bioethanol for cars and motorcycles, E10 for other gasoline and hybrid vehicles and the use of B20 biodiesel in all diesel vehicles.

In addition to the increased use of renewable energy in these scenarios, and the associated $\mathrm{CO}_{2}$ eq. savings, increased biofuel use will also affect pollutant emissions from road transport since the composition of blended fuels affects these emissions. Information on the vehicle fleet in 2017, fuel consumption and travel distance by vehicle type (Table A1 in the Appendix A) and the EMEP/EEA emission factors [42] were used to calculate the pollutant emissions for the scenarios and the baseline case (Table A2 in the Appendix A). Tier 1 emission factors (minimum values as a conservative estimate) were used in all cases except for bioethanol for cars and motorcycles, for which Tier 2 emission factors were used. For biodiesel, for which no data was available, Tier 1 diesel emission factors were used. The changes in emissions for each scenario were calculated as a percentage of the baseline emissions and this emission variation (Table A3 in the Appendix A) was applied to the emissions for SNAP 7 (Road Transport, according to the Selected Nomenclature for Air Pollution developed in the CORINAIR and synchronized with the IPCC/OECD nomenclature of source categories for activities resulting in emissions [43]) in the national emission inventory for 2017. Figure 1 shows the change in total emissions by scenario and pollutant, with respect to the baseline. These scenarios achieve modest reductions in emissions of NMVOC (both scenarios), NOx (BioEt only) and $\mathrm{PM}_{2.5}$ and $\mathrm{PM}_{10}$ (Biof only) but also increase total emissions of $\mathrm{NH}_{3}$ by about 1\%. Figure A1 (in the Appendix A) shows the spatial distribution of the emission reductions.

\subsubsection{Full Penetration of the Electric Car}

The scenario EC consists of replacing all diesel and gasoline passenger cars (except hybrids) with electric cars. The result is a substantial reduction in direct pollutant emissions, since the exhaust emissions from vehicles are completely removed. However, non-exhaust emissions of particles (e.g., from tire and brake wear, road abrasion and resuspension from the surface) would not be reduced and would actually increase substantially due to the fact that EV are heavier than equivalent internal combustion engine vehicles by approximately $24 \%$ [44], although the increase is small compared with the reduction in exhaust emissions.

Despite the fact that the motors of electric cars do not directly emit pollutants, the production of the electricity required for charging them can be an important emission source, depending on the power generation technology. For the calculation of the additional power required for charging (included in scenario EC-E), the additional electric car use for this scenario was calculated. This was done by calculating the car use (in vehicles $\cdot \mathrm{km}, \mathrm{vkm}$ ) for vehicles of all fuel types in 2017 that are substituted by electric cars in this scenario. However, the NECP already includes the addition of five million new electric cars for 2030 and, therefore, these need to be subtracted to avoid double counting in the calculation of additional electricity demand (Table 2). The measure will consist of an additional 
$2.26 \cdot 10^{11} \mathrm{vkm}$ for electric cars. Since the electricity consumption by electric cars was $0.140 \mathrm{kWh} / \mathrm{vkm}$ in 2017 (on average), the total additional power demand to support the new electric cars will be $31.6 \mathrm{TWh}$.

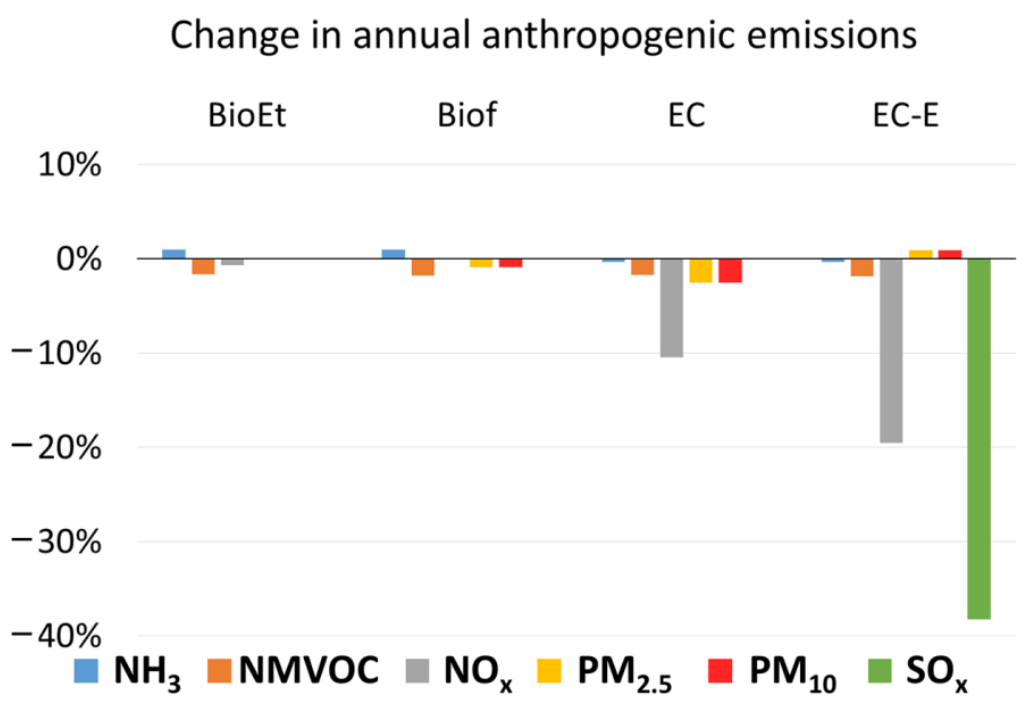

Figure 1. Change in total annual anthropogenic emissions of the air pollutants included in this study by scenario and pollutant, with respect to the baseline emissions (2017). The scenarios are: BioEt (use of E85 biofuel in passenger cars and motorcycles and E10 in other petrol vehicles), Biof (use of E85 in passenger cars and motorcycles, E10 in other petrol vehicles and B20 in diesel vehicles), EC (substitution of all passenger cars, except hybrids, by electric cars) and EC-E (substitution of all passenger cars, except hybrids, by electric cars and including the emissions from the additional electricity demand).

Table 2. Existing passenger car fleet in 2017 in Spain and the car use (vkm) substituted by the additional electric fleet.

\begin{tabular}{|c|c|c|c|c|c|c|}
\hline & $\begin{array}{l}\text { No. Vehicles } \\
\text { in } 2017\end{array}$ & $\begin{array}{l}\text { \% Vehicles } \\
\text { in } 2017\end{array}$ & $\begin{array}{l}\text { Number of Vehicles } \\
\text { Substituted by Electric } \\
\text { Cars in NIECP for } 2030\end{array}$ & $\begin{array}{l}\text { Number of Vehicles } \\
\text { Substituted by Electric } \\
\text { Cars in the EC Scenarios }\end{array}$ & $\begin{array}{c}\text { Annual } \\
\text { Distance } \\
(\mathrm{km} / \text { car/year })\end{array}$ & $\begin{array}{l}\text { Annual Additional EV } \\
\text { Car Use (vkm/year) }\end{array}$ \\
\hline Diesel & $13,611,088$ & $63.38 \%$ & $3,168,859$ & $10,442,229$ & 16,522 & $1.72 \times 10^{11}$ \\
\hline Biodiesel & 0 & $0.00 \%$ & 0 & 0 & 0 & 0 \\
\hline Petrol & $7,452,327$ & $34.70 \%$ & $1,735,010$ & $5,717,317$ & 8696 & $49,717,787,295$ \\
\hline Bioethanol & 209,239 & $0.97 \%$ & 48,714 & 160,525 & 8696 & $1,395,926,413$ \\
\hline LPGs & 44,872 & $0.21 \%$ & 10,447 & 34,425 & 16,522 & $568,772,254$ \\
\hline $\mathrm{CNG}$ & 158,796 & $0.74 \%$ & 36,970 & 121,826 & 16,522 & $2,012,808,855$ \\
\hline EV/hybrid & 12,170 & $0.06 \%$ & 0 & 0 & 9566 & \\
\hline Total & $21,488,491$ & $100 \%$ & $5,000,000$ & $16,476,321$ & & $2.26 \times 10^{11}$ \\
\hline
\end{tabular}

The pollutant emissions associated with the generation of this additional electricity depends on how it is produced. These emissions have been calculated for the baseline (2017) and the EC-E scenario (2030) using the emission factors from the most recent EMEP/EEA guide [42] and taking into account the changes in the energy mix in Spain for 2030 included in the NECP. In 2017, fossil fuel combustion technologies (SNAP 1: combustion in the production and transformation of energy) produced $45 \%$ of the electricity generated in Spain [45]. This contribution is expected to decrease to 18\% in 2030 under the NECP. As a result of these changes in the energy mix, SNAP 1 emissions for the EC-E scenario are actually lower for all pollutants, except $\mathrm{PM}_{2.5}$, with respect to the baseline emissions, even though electricity demand is higher (Table A2). Total anthropogenic emissions for all pollutants except $\mathrm{PM}_{2.5}$ are also lower than those in the EC scenario. 


\subsection{Air Quality Modeling}

The air quality modeling provides the basis for the health impact assessment (HIA) and external cost analyses of the scenarios studied. Air quality estimates were obtained from simulations performed with the CHIMERE model [46], which was applied to a domain covering the Iberian Peninsula at a spatial resolution of $0.1^{\circ} \times 0.1^{\circ}$ nested within a European domain at $0.15^{\circ} \times 0.15^{\circ}$. The CHIMERE model has been extensively used and evaluated in Europe [47] and, in particular, in Spain [48-50]. Model performance for estimating atmospheric concentrations has been shown to be comparable to that of other air quality models applied in Europe [51]. To estimate the impacts of the scenarios relative to the baseline, emissions for 2017 provided by the Ministry for the Ecological Transition and Demographic Challenge (METDC) were used. These emissions are based on the National Official Emission Inventory for 2017, calculated at a spatial resolution of $0.1^{\circ} \times 0.1^{\circ}$ (EMEP grid). Emissions for the scenarios were calculated by applying the emission changes for SNAP 1 and SNAP 7 (Table A2 in the Appendix A) to each model grid cell. Meteorological data were obtained from simulations of the Integrated Forecasting System (IFS) of the European Centre for Medium-Range Weather Forecasts (ECMWF (www.ecmwf.int, accessed on 20 October 2021)) for 2017, which were obtained from the MARS archive at the ECMWF through the access provided for research projects by the Spanish State Meteorological Agency (AEMET). Specifically, we have used the HRES (Atmospheric Model high resolution) model with a horizontal resolution of approximately $9 \mathrm{~km}$ and 137 levels in the vertical. The same meteorology was used for the baseline and the scenarios in order to evaluate impacts only due to changes in emissions.

Annual mean concentrations for $\mathrm{SO}_{2}, \mathrm{NO}_{2}, \mathrm{PM}_{10}$ and $\mathrm{PM}_{2.5}$ were calculated, as well as $\mathrm{SOMO} 35$ for $\mathrm{O}_{3}$. This metric for ozone is defined as the sum of means over $35 \mathrm{ppb}$ (daily maximum 8-h) [52]. For the use in this study, following the recommendation of [53], the result is converted to a change in annual daily maximum 8-h mean in excess of $35 \mathrm{ppm}$, divided by the number of days in the year of the calculation [54]. Since the estimation of impacts and costs strongly depends on the accuracy of the air quality estimates, the model outputs were combined with observations to reduce spatiotemporal biases resulting from model or input data uncertainty. The methodology for combining the model estimates with the observations is more fully described in [36]. The same corrections were applied to the scenarios by assuming that the biases (calculated for the 2017 baseline) are proportional to the atmospheric concentrations.

\subsection{Impact Assessment}

\subsubsection{Mortality Impact Assessment Methodology}

The impacts on premature mortality were estimated following the recommendations issued by the Health Risks of Air Pollution in Europe (HRAPIE) project $[53,55]$. This project proposed concentration-response functions (CRF) for key pollutants to be included in cost-benefit analysis supporting air quality policy, considering the meta-analysis and the findings from the project Review of Evidence on Health Aspects of Air Pollution (REVIHAAP) [56]. The methodology allows the estimation of health impacts by using the concentrations simulated by the air quality model and the recommended CRF. Only mortality impacts have been considered. The key pollutants are particulate matter (PM), nitrogen dioxide $\left(\mathrm{NO}_{2}\right)$ and ozone $\left(\mathrm{O}_{3}\right)$. The input data required for the assessment includes demographic (population) and health data (baseline mortality), as well as the modeled pollutant concentrations.

The mortality impact expresses the number of attributable premature deaths associated to a pollutant exposure and is calculated as the product of the concentration change in the pollutant with respect to the baseline (2017), the fraction of the population for the age group considered, the fraction of population at risk within the age group, the incidence ratio existing in the population under study and the CRF, which indicates the change in incidence per unit of concentration. 
The CRF values are given as relative risks (RR). Relative risks (RR) have an uncertainty that is expressed as confidence intervals (CIs). These CIs provide the upper and lower boundaries of the $95 \% \mathrm{CI}$ of the estimate. Table 3 summarizes the CRFs used in this study to assess mortality impacts. Only those effects that contribute to the total effect-additive effects-are considered and the effects of both Group A* and Group B* are quantified.

Table 3. Concentration Response Functions (CRF) recommended for mortality impact assessment [39] and used in the study.

\begin{tabular}{|c|c|c|c|c|c|}
\hline $\begin{array}{l}\text { Pollutant and } \\
\text { Metric }\end{array}$ & $\begin{array}{c}\text { Range of } \\
\text { Concentration }\end{array}$ & $\begin{array}{c}\text { Health Outcome } \\
\text { (Impact/Population Group) }\end{array}$ & Type $^{\dagger}$ & $\begin{array}{l}\text { RR }(95 \% \text { CI }) \text { per } \\
\quad 10 \mu \mathrm{g} / \mathrm{m}^{3}\end{array}$ & Source \\
\hline $\mathrm{NO}_{2}$, annual mean & $>20 \mu \mathrm{g} / \mathrm{m}^{3}$ & $\begin{array}{l}\text { Long-term Mortality, all (natural) } \\
\text { causes, age over } 30 \text { years }\end{array}$ & $\mathrm{B}^{*}$ & $1.055(1.031-1.080)$ & [57] \\
\hline $\mathrm{NO}_{2}$, annual mean & All & $\begin{array}{c}\text { Acute Mortality, all (natural) causes, } \\
\text { all ages }\end{array}$ & $A^{*}$ & $\begin{array}{c}1.0027 \\
(1.0016-1.0038)\end{array}$ & [58] \\
\hline $\mathrm{O}_{3}, \mathrm{SOMO} 35$ & $\begin{array}{c}>35 \mathrm{ppb} \\
\left(>70 \mu \mathrm{g} / \mathrm{m}^{3}\right)\end{array}$ & Mortality, all (natural) causes, all ages & $A^{*}$ & $\begin{array}{c}1.0029 \\
(1.0014-1.0043)\end{array}$ & {$[59,60]$} \\
\hline $\begin{array}{l}\mathrm{PM}_{2.5} \text {, annual } \\
\text { mean }\end{array}$ & All & $\begin{array}{c}\text { Mortality, all (natural) causes, age } \\
\text { over } 30 \text { years, expressed as Y }\end{array}$ & $A^{*}$ & $1.062(1.040-1.083)$ & [57] \\
\hline $\begin{array}{l}\mathrm{PM}_{10} \text {, annual } \\
\text { mean }\end{array}$ & All & $\begin{array}{l}\text { Post-neonatal infant mortality, (age } \\
1-12 \text { months), all (natural) causes }\end{array}$ & $\mathrm{B}^{*}$ & $1.04(1.02,1.07)$ & [61] \\
\hline
\end{tabular}

† Type $\mathrm{A}^{*}$ : pollutant-outcome effects for which enough data are available for a reliable quantification; Type $\mathrm{B}^{*}$ : pollutant-outcome effects for which there is more uncertainty.

\subsubsection{Data Used and the HIA Model}

As previously mentioned, the pollutant concentrations are estimated for the scenarios of 2030 for the measures implemented. The area of study is the Spanish territory of the Iberian Peninsula and Balearic Islands. A GIS model was used for the HIA based on these gridded concentration data and a population density map was created for the same grid. The Spanish population (official census data [62]) by age and settlement was disaggregated over the grid cells using the settlement centroids. When cities, villages or even lower-level settlements covered more than one grid cell, the population was distributed between the cells according to the population within each grid cell. The estimated rate of growth for the population projected to 2030 was obtained from the National Statistics Institute (INE), based on the official census [63]. This growth was applied to the population in every scenario of implementation of the measures, allowing the comparison between measures. A sensitivity analysis comparing the results with and without projection of the population of the reference scenario is presented in the Discussion section.

Mortality rates by age and regional location at the NUTS3 level were then allocated to each cell. The Nomenclature of Territorial Units for Statistics (NUTS) was developed by the European Union for the production of regional statistics and for targeting political interventions at a regional level. In Spain, the territory is organized by the administrative boundaries corresponding to 17 Autonomous Communities and 2 Autonomous Cities (Comunidades y ciudades autónomas) at the NUTS2 level, and 57 Provinces (Provincias) at the NUTS3 level [64]. Official health data on mortality for 2017 were used as the baseline incidence of mortality rates and age group. More specifically, the data on the number of deaths corresponding to total non-accidental causes (International Classification of Diseases, 10th revision [ICD-10], codes A00-R99) from the INE database were used.

\subsubsection{External Costs}

Impacts on mortality in terms of premature deaths have been converted into costs (external costs) by assuming a monetary valuation for them, using the Value of Statistical Life (VSL) [65]. The VSL is a commonly-used economic method of valuing risk to life which is derived from the trade-offs people are willing to make between fatality risk and wealth — it might be alternately phrased 'the value of preventing a fatality' [66]. There are several published estimates of VSL in the literature, including studies and meta-analyses considering different variables (e.g., age [67] or labor market, such as Vis- 
cusi $[68,69])$. In this study, the monetary valuation is based on the VSL proposed as a result of the meta-analysis of a large number of studies of individuals' willingness to pay (WTP) for a marginal reduction in their risk of mortality over time, carried out by the OECD in 2012 [70].

Additionally, the VSL has been adjusted according to country and time as proposed by the more recent publications from the OECD. For this, we have used a methodology adapted from Roy and Braathen [71], in which income is used as the reference variable to adapt WTP over time, so as to avoid situations in which the WTP to save a life rises faster over time than the rate of inflation. Thus, the VSL for Spain in 2019 has been calculated by adjusting and updating the VSL for OECD countries in 2015, considering the change in Gross Domestic Product (GDP) per capita between 2015 and 2019, as well as the variation in the currency value - variation in the Harmonized Consumer Price Index (HCPI), (4.3\% according to data provided by INE [72])—and an income elasticity of 0.8 , as is recommended for high-income countries (within the 40th percentile). The year 2019 has been selected with the aim of avoidin the influence or deviation of the normal evolution of these rates (GDP or HCPI) caused by the COVID-19 pandemic. The income elasticity variable assumes that, as incomes rise, the WTP for a marginal reduction in the risk of death also rises, however, not quite in proportion to the rise in incomes. The monetary valuation of infant mortality is taken from the recommendations from OECD [73] (Average value of High and Low Value), and are updated to the present value by a currency conversion from $€_{2005}$ to $€_{2019}$ in order to take inflation into account. Table 4 shows monetary values used for the health impact assessment.

Table 4. Monetary values (V) used for the health impact assessment in $€_{2019}$.

\begin{tabular}{cccc}
\hline Pollutants & Health Outcome & $\begin{array}{c}\text { Value of VSL or Premature } \\
\text { Death in Spain }\left(\boldsymbol{\epsilon}_{\mathbf{2 0 1 9}} / \text { Unit) }\right.\end{array}$ & Source \\
\hline $\mathrm{NO}_{2}, \mathrm{O}_{3}, \mathrm{PM}$ & Mortality (VSL) & $3,998,266.36$ & Calculated, OECD [71] \\
$\mathrm{PM}_{10}$ & Infant mortality & $6,747,300.00$ & OECD [73], Average of High and Low Values \\
\hline
\end{tabular}

\section{Results}

The results on air quality, mortality impact assessment and the monetary valuation of the implemented measures are presented in this section. A descriptive statistical table of data (population, air pollution and mortality) obtained along the domain as an analysis of values of cells is shown in the Table A4 in the Appendix A. First, the results on air quality are presented, showing the changes in the air pollutant concentrations for each scenario. Second, the results on mortality and external costs are presented in terms of avoided mortality, i.e., the difference between the premature deaths attributable to air pollution in the baseline and the scenarios. In this study, the avoided impact should be interpreted as the potential to avoid premature deaths in the future. Similarly, the avoided external costs associated with air pollution are the difference between the external costs of the baseline and the scenarios.

\subsection{Air Quality Results}

Figure 2 shows the relative changes in atmospheric concentrations of the pollutants associated with health impact for the four scenarios with respect to the baseline. With regards to $\mathrm{NO}_{2}$, the two electric car scenarios reduce annual mean concentrations the most, due to their larger emission reductions with respect to the two biofuel scenarios. Although concentration reductions for EC and EC-E are similar for most of the domain, there are larger reductions in the EC-E scenario in the northwest, where two of the largest coal-fired power stations are located that are not included in the energy mix for 2030. Similarly, the two electric car scenarios reduce PM concentrations the most. For $\mathrm{PM}_{2.5}$, the EC-E scenario reduces the concentrations the most, despite an increase in PM emissions with respect to the baseline. This is due to the substantial reduction in $\mathrm{SO}_{\mathrm{x}}$ emissions (by $38.3 \%$ ) 
through the elimination of coal-fired power stations in the 2030 energy mix. Lower $\mathrm{SO}_{\mathrm{x}}$ emissions lead to less formation of secondary particles (mostly ammonium sulfate) and, hence, lower $\mathrm{PM}_{2.5}$ concentrations. By contrast, the BioEt scenario actually increases PM concentrations in the center of the domain (near Madrid), despite having practically the same PM emissions as the baseline. This is due to the increase in $\mathrm{NH}_{3}$ emissions, especially in Madrid (Figure A1 in Appendix A), leading to an increase in secondary particle formation (mostly ammonium nitrate). In the Biof scenario, the increased $\mathrm{NH}_{3}$ emissions also lead to an increase in particle formation; however, the impact of this increase is partially or fully offset by the decrease in PM emissions $(0.9 \%)$. The two biofuel scenarios have a very small impact on $\mathrm{O}_{3}$ concentrations (SOMO35), whereas the electric car scenarios reduce concentrations for large areas of the domain as a result of larger reductions in precursor emissions (mostly $\mathrm{NO}_{\mathrm{x}}$ ).

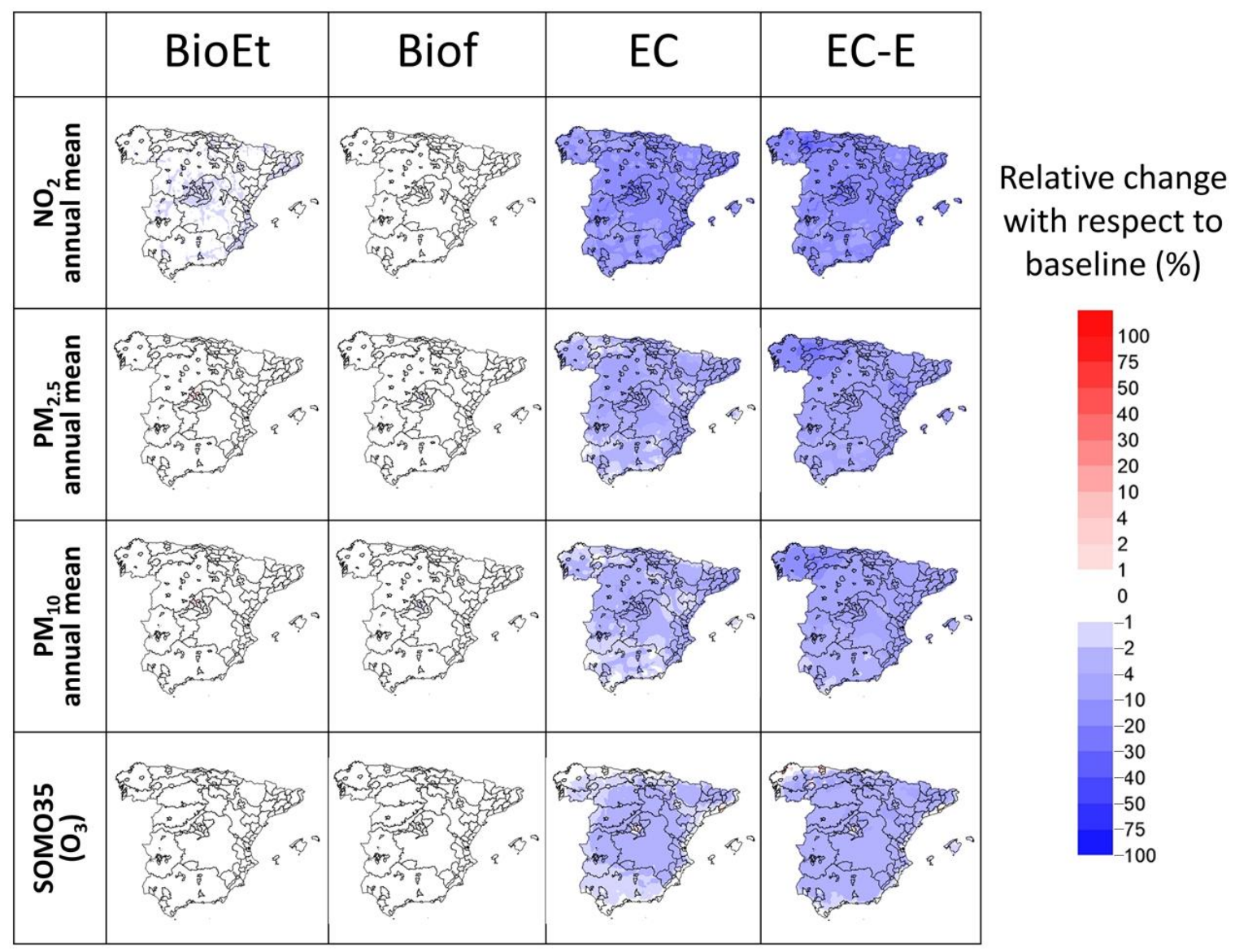

Figure 2. Change in air quality indicators with respect to the baseline values (2017) of each scenario: BioEt (use of E85 biofuel in passenger cars and motorcycles and E10 in other petrol vehicles), Biof (use of E85 in passenger cars and motorcycles, E10 in other petrol vehicles and B20 in diesel vehicles), EC (substitution of all passenger cars, except hybrids, by electric cars) and EC-E (substitution of all passenger cars except hybrids by electric cars and including the emissions from the additional electricity demand). Maps show the air quality assessment zones for the Spanish territory of the Iberian Peninsula, Balearic Islands, Ceuta and Melilla.

\subsection{Avoided Mortality}

Table 5 presents the results of avoided mortality by pollutant for each scenario. These results show that the scenarios that most reduce $\mathrm{NO}_{2}$ (EC and EC-E) lead to the highest reduction in premature deaths. The difference between the avoided mortality for the EC scenarios is small, with the highest value for the scenario that includes the increased demand and the contribution of renewable power production estimated in the NECP (ECE). Despite the increase in power demand, this scenario actually has the lowest mortality. 
This is mainly due to the expected decarbonization of the electricity mix in 2030, since the additional emissions are added to a cleaner power system. In the scenario EC-E, coal-based power production is completely removed and other fossil sources decrease remarkably in favor of renewables such as wind or photovoltaics.

Table 5. Number of avoided premature deaths, by pollutant and scenario. " $\mathrm{NO}_{2} \mathrm{ac}$ " is acute mortality and " $\mathrm{PM} 10 \mathrm{inf}$ " is infant mortality. Results in red highlight the negative results for avoided mortality (i.e., more premature deaths). The numbers in brackets are the values calculated using the upper and lower values of RR with the $95 \%$ IC.

\begin{tabular}{ccccc}
\hline & BioEt & Biof & EC & EC-E \\
\hline Unit & & Avoided premature deaths (number) & \\
$\mathrm{NO}_{2}$ & $331(323-339)$ & $18(17-18)$ & $4771(4663-4884)$ & $4839(4729-4954)$ \\
$\mathrm{NO}_{2} \mathrm{ac}$ & $19(19-19)$ & $1(1-1)$ & $299(299-300)$ & $313(313-314)$ \\
$\mathrm{PM}_{2.5}$ & $-123(-144--120)$ & $110(107-703)$ & $1387(1358-1414)$ & $1931(1891-1969)$ \\
$\mathrm{PM}_{10}$ inf & $-0.1(-0.45--0.08)$ & $0.14(0.14-0.67)$ & $1.14(1.11-1.17)$ & $1.5(1-2)$ \\
$\mathrm{O}_{3}$ & $5(5-5)$ & $5(5-5)$ & $8(8-8)$ & $28(28-28)$ \\
Total & $231(219-227)$ & $133(130-728)$ & $6467(6329-6607)$ & $7113(6963-7266)$ \\
\hline
\end{tabular}

Interestingly, a reduction in total $\mathrm{NO}_{\mathrm{x}}$ emissions of $10.4 \%$ in the EC scenario reduces premature deaths due to exposure to $\mathrm{NO}_{2}$ by 5070 (long-term plus acute avoided mortality), whereas the larger reduction in $\mathrm{NO}_{\mathrm{x}}$ emissions in the EC-E scenario (19.6\%) only leads to an additional reduction of 82 premature deaths ( 4839 plus 313 premature deaths). This is because the additional reduction in $\mathrm{NO}_{\mathrm{x}}$ emissions (from fossil-fuel electricity generation) is very localized and, therefore, the population that benefits from these reductions is smaller. The reduction in mortality due to $\mathrm{PM}_{2.5}$ exposure is also greater for the EC-E scenario. In contrast to the EC scenario, this reduction is not due to decreased $\mathrm{PM}_{2.5}$ emissions but is the result of the large reductions in $\mathrm{SO}_{\mathrm{x}}$ emissions, as described above. The variation in the air pollution-related mortality with respect to the baseline (2017) is shown in Figure 3. The change in mortality due to the adoption of electric cars with respect to the baseline is a reduction of $14.4-15.9 \%$, with a large influence in the reduction of $\mathrm{NO}_{2}$ concentrations (reduction in mortality of 39.2-39.8\%).

The impact reductions of the biofuel measure scenarios are much lower than the EC scenarios as a result of smaller emission reductions. In the BioEt scenario, the increased particle formation due to the larger $\mathrm{NH}_{3}$ emissions increases mortality from exposure to PM; however, this increase is more than compensated for by the reduction in mortality due to exposure to $\mathrm{NO}_{2}$ and $\mathrm{O}_{3}$, leading to a net benefit. The Biof scenario also has a net benefit in terms of avoided premature deaths, mostly due to a reduction in exposure to PM.

With regards to the spatial distribution of impacts, the change in mortality impacts with respect to the 2017 baseline is irregularly distributed throughout the domain (Figure 4). In the BioEt and Biof scenarios, there are slight reductions in mortality (very light blue) for most of the domain. However, there are very small increases in the city of Madrid and the surrounding urban areas (light red, center of the domain) as a result of secondary particle formation. By contrast, the EC scenarios reduce mortality (blue areas) for the whole domain. Comparing the scenarios, EC and EC-E, there are differences associated with the contribution of power generation from fossil technologies. Larger reductions in mortality are estimated for the scenario with an increased share of renewable energy in 2030 (EC-E), especially in the northwest of the domain where two of the largest coal-fired power stations are located. 


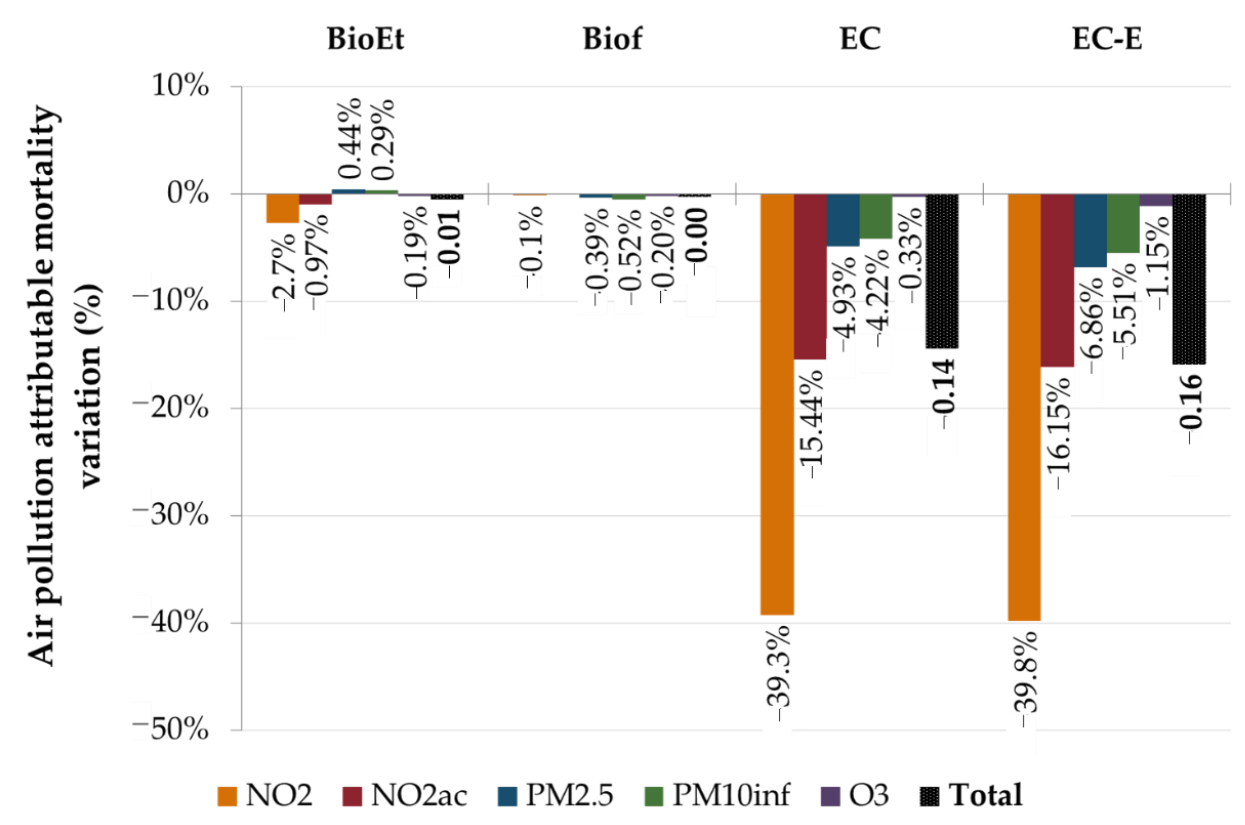

Figure 3. Variation in mortality attributable to air pollution (\%) with respect to the baseline by pollutant and scenario. The scenarios are: BioEt (use of E85 biofuel in passenger cars and motorcycles and E10 in other petrol vehicles), Biof (use of E85 in passenger cars and motorcycles, E10 in other petrol vehicles and B20 in diesel vehicles), EC (substitution of all passenger cars, except hybrids, by electric cars) and EC-E (substitution of all passenger cars, except hybrids, by electric cars and including the emissions from the additional electricity demand).

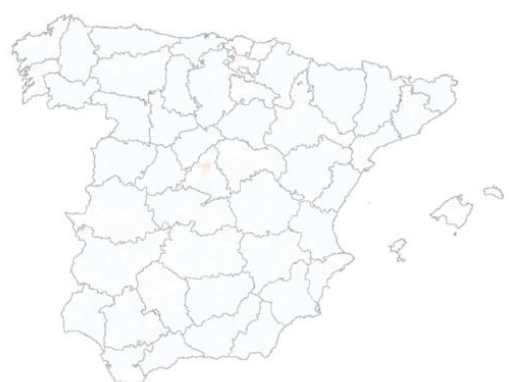

(a)

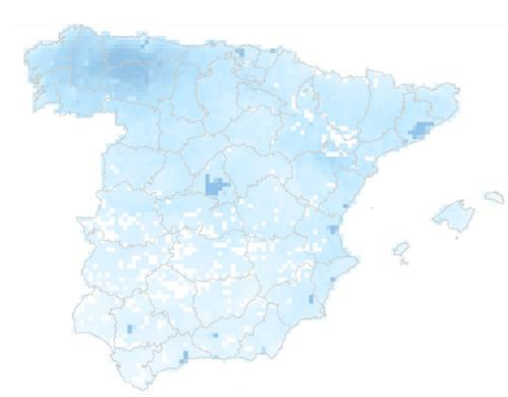

(c)

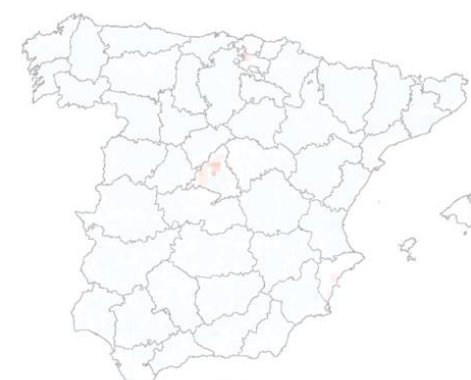

(b)
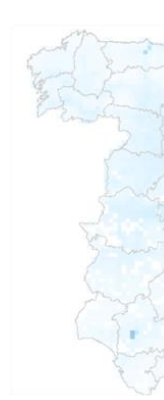

(3)

Figure 4. Spatial distribution of the relative change in mortality attributable to air pollutant emissions for the four scenarios: (a) BioEt; (b) Biof; (c) EC and (d) EC-E, with respect to the reference scenario. The scenarios are BioEt (use of E85 biofuel in passenger cars and motorcycles and E10 in other petrol vehicles), Biof (use of E85 in passenger cars and motorcycles, E10 in other petrol vehicles and B20 in diesel vehicles), EC (substitution of all passenger cars, except hybrids, by electric cars) and EC-E (substitution of all passenger cars, except hybrids, by electric cars and including the emissions from the additional electricity demand). 


\subsection{Avoided External Costs of Mortality Due to Air Pollution}

Results for the external costs are presented in the Table 6 and the Figure 5. The social impact on mortality due to the improvement or worsening of air quality is considered a benefit when the avoided impact, with respect to the baseline (external cost), is positive and as a loss of wellbeing when the result is negative, i.e., mortality is increased. These results show that all four scenarios are estimated to provide a net benefit, with the two EC scenarios providing the largest benefits. Of the two biofuel scenarios, BioEt provides the largest benefit as a result of reductions in exposure to $\mathrm{NO}_{2}$, even though these are partially compensated for by the increased exposure to PM.

Table 6. Avoided external costs associated with the impact of air pollution on mortality with respect to the baseline (in millions of $€_{2019}$ ). Results in red highlight the negative avoided external costs associated with mortality (i.e., an increase in mortality).

\begin{tabular}{ccccc}
\hline & BioEt & Biof & ECA & ECB \\
\hline Unit & \multicolumn{3}{c}{ Million $€_{2019}$} \\
$\mathrm{NO}_{2}$ & 1323 & 71 & 19,077 & 19,347 \\
$\mathrm{NO}_{2}$ ac & 75 & 2 & 1197 & 1252 \\
$\mathrm{PM}_{2.5}$ & -493 & 439 & 5546 & 7722 \\
$\mathrm{PM}_{10}$ inf & -1 & 1 & 8 & 10 \\
$\mathrm{O}_{3}$ & 19 & 20 & 32 & 113 \\
Total & 923 & 533 & 25,860 & 28,444 \\
\hline
\end{tabular}

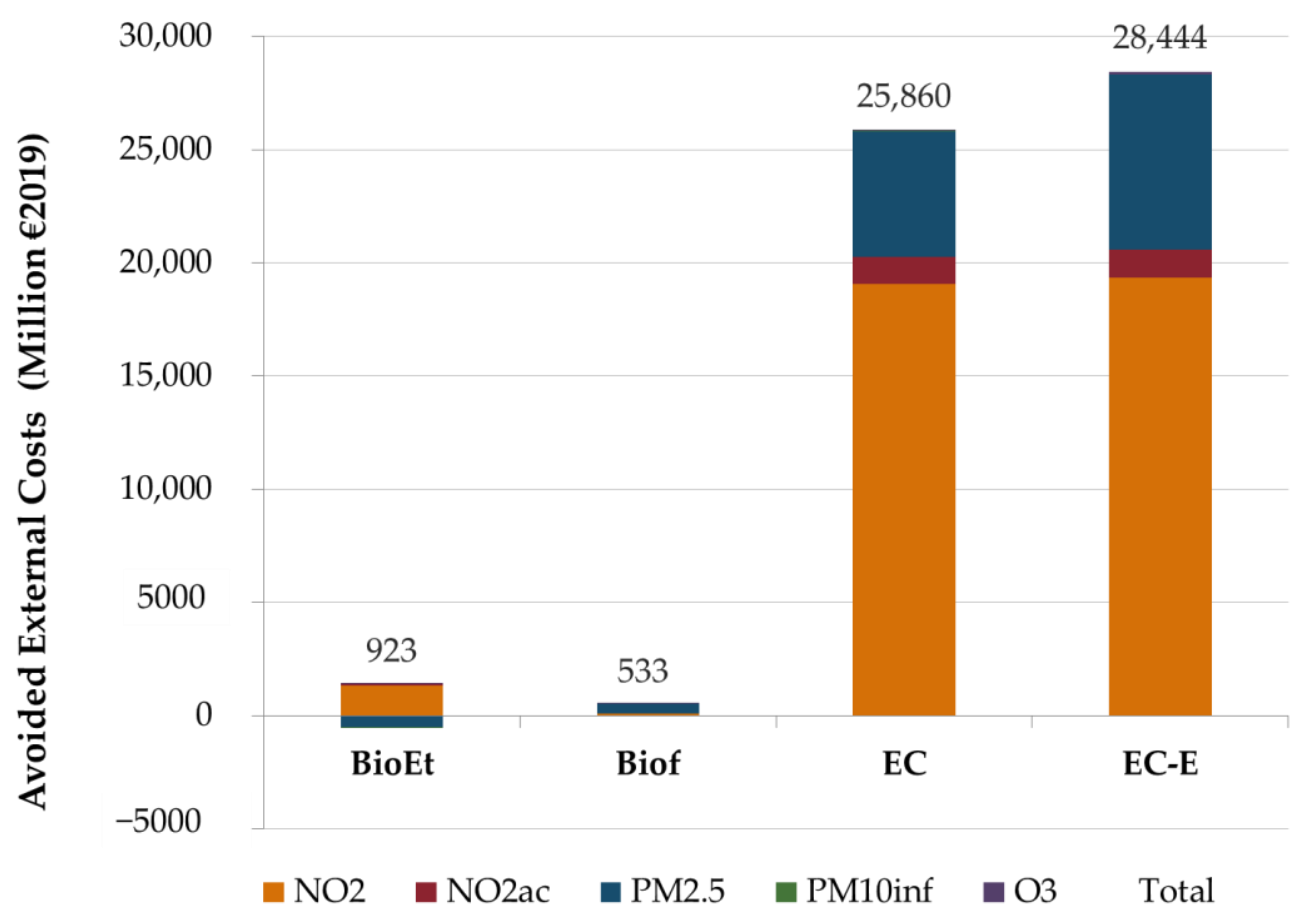

Figure 5. Avoided external costs associated with mortality attributed to ambient air pollutants. The scenarios are: BioEt (use of E85 biofuel in passenger cars and motorcycles and E10 in other petrol vehicles), Biof (use of E85 in passenger cars and motorcycles, E10 in other petrol vehicles and B20 in diesel vehicles), EC (substitution of all passenger cars, except hybrids, by electric cars) and EC-E (substitution of all passenger cars, except hybrids, by electric cars and including the emissions from the additional electricity demand).

\section{Discussion}

There is a wide range of strategies that can be applied to the mobility and transportation sector to reduce its environmental and social impact in Europe. Among these, one 
of the most promising alternatives is the electrification of the road fleet combined with increases in renewable energy production, which also meets the objectives of decarbonization. However, there are difficulties associated with this scenario. The capacity to increase the contribution of renewables sufficiently by 2030, the development of energy storage technologies to handle the variability of renewables or the impacts of the whole life cycle of electric cars and, specifically, battery life, could be barriers to achieving ambitious objectives for the electrification of the road transportation and mobility sector. Furthermore, the current rate of climate change requires a fast shift, which implies a broad and accelerated deployment of strategies involving large infrastructure developments and investments to move the energy sector towards a more sustainable model. In this sense, biofuels are one option to mitigate climate change in the short-term, since they offer the advantage of being compatible with the current fleet of road transport based on (modified) petrol and diesel fueled vehicles.

In Europe, the implementation and regulation of biofuel in petrol and diesel takes time, and the change has been modest so far. To date, Spain has complied with its objectives in terms of GHG reduction by including biofuels in the fuel pool [74]. However, the increased use of biofuels has some negative impacts, such as those to human health due to increasing air pollution, as we show in this study, and other impacts throughout their production life cycle such as changes in land use, water depletion, etc., that depend on the source of raw materials and production techniques. First- and second-generation biofuels could also have pollution swapping issues. One example of this is the contribution to global warming of $\mathrm{N}_{2} \mathrm{O}$ emissions from fertilizers applied to biofuel crops in the field, which, in some cases, could lead to larger GHG emissions (in $\mathrm{CO}_{2}$ eq.) than the petrol and diesel they are supposed to replace [75].

In this paper, the proposed scenarios with measures for increased renewable energy for mobility are supposed to offer a co-benefit for the pathway to sustainability. In order to demonstrate the co-benefits between ambient air impacts on health and GHG mitigation, the global warming potential associated with the scenarios has been estimated, as well as the external costs associated with the principal GHGs $\left(\mathrm{CO}_{2}, \mathrm{NO}_{2}\right.$ and $\left.\mathrm{CH}_{4}\right)$. In terms of Life Cycle Assessment, these are known as well-to-wheel GHG emissions (excluding the vehicle manufacturing). For this purpose, the GHG emissions associated with fuel production have been calculated considering the well-to-tank emissions reported by the JRC (GHG life cycle emissions of fuel production) for diesel, petrol, ethanol and biodiesel fuels [76,77], as well as the GHG emissions from the combustion stage for fuels. In the case of electricity generation for EC, the life cycle GHGs of the projected power mix in Spain for 2030 (based on the composition of the generation power mix in NECP [3]) have been calculated by using the Ecoinvent database $[78,79])$. The emission factors for combustion processes in vehicles were obtained from the EMEP/EEA air pollutant emission inventory guidebook [80] and the scientific literature (Lechon et al. [81,82]). Thus, by summing the GHGs emissions by stages, the well-to-wheel GHG emissions are obtained. A fraction of those emissions is renewable $\mathrm{CO}_{2}$ since they have a biogenic origin, in the case of biofuels and biomass power. Finally, external costs associated with the GHG emissions have been calculated by applying the damage factors developed in the CASES project [83] that quantify climate change induced damages. Figure 6 shows the estimated GHG emissions ( $\mathrm{kg}$ of $\mathrm{CO}_{2}$ eq.) for the four scenarios (EC scenario is excluded since it does not consider the power production), as well as the external costs and avoided costs with respect to the baseline. GHG emissions are estimated to be lower for all four scenarios with the electromobility scenario (EC-E), giving the lowest emissions. In contrast to the impact on mortality due to air pollution, the benefits of both biofuel measures are positive (Figure 6c, avoided external costs) and closer to the benefits from $\mathrm{EC}$, with respect to the baseline. In the case of biofuels, the impact of reducing GHG is positive and even compensates the external costs associated with health impacts. Therefore, policy design has to take into account that increased biofuel use could be effective with respect to climate change and air quality, and related health impacts in 
general, but have negative impacts for specific pollutants in some highly populated areas (mortality associated with PM exposure).

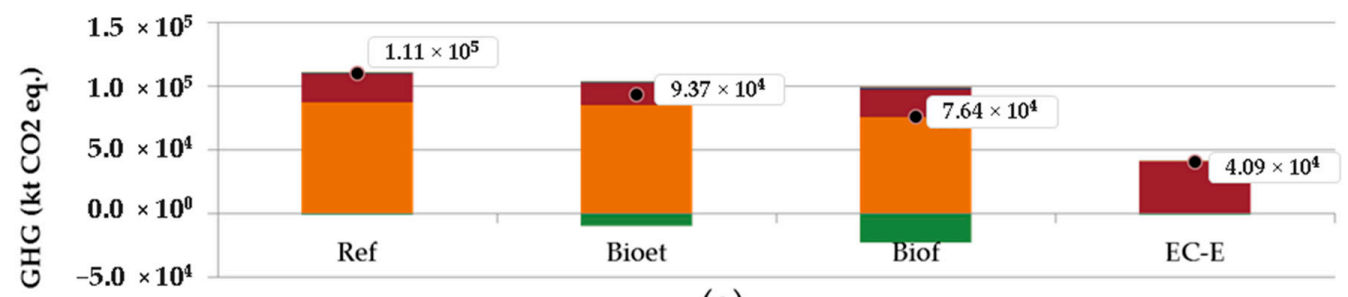

(a)

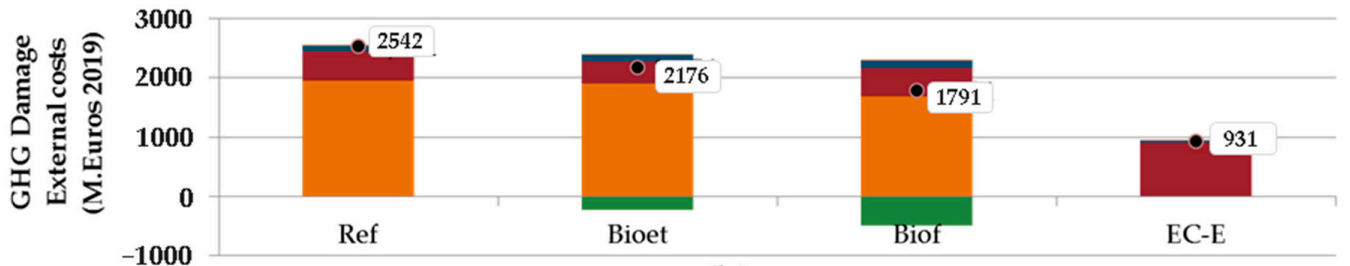

(b)

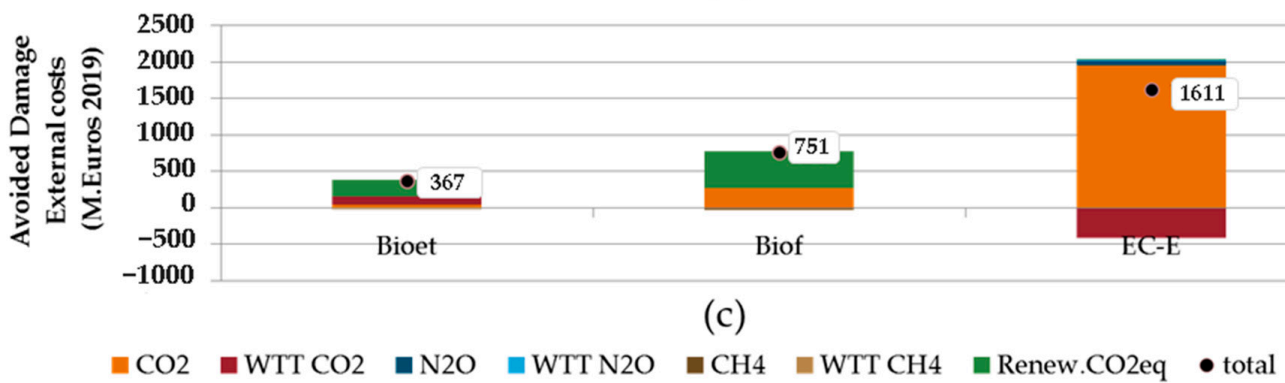

Figure 6. GHG impact analysis of the four scenarios. The top figure (a) is the well-to-wheel GHG emissions associated with each scenario, the middle figure (b) shows the external costs associated with the climate impacts and the bottom figure (c) shows the avoided GHG damage external costs associated with the scenarios with respect to the baseline (Ref). The scenarios are: BioEt (use of E85 biofuel in passenger cars and motorcycles and E10 in other petrol vehicles), Biof (use of E85 in passenger cars and motorcycles, E10 in other petrol vehicles and B20 in diesel vehicles), EC (substitution of all passenger cars, except hybrids, by electric cars) and EC-E (substitution of all passenger cars, except hybrids, by electric cars and including the emissions from the additional electricity demand).

When comparing the total avoided impacts and assessing the co-benefits in terms of external costs, various considerations and limitations of the study must be taken into account. For the design of policies for road transport and mobility, the population exposure is critical. The highest negative impacts associated with biofuels are estimated to be in the most populated urban areas (e.g., Madrid). This fact, combined with other considerations such as EV autonomy, highlights the need to prioritize the adoption of EV in those urban areas where biofuel measures lead to increases in mortality.

Limitations and assumptions made in the assessment must be taken into account when interpreting the results. Regarding the strategy design (Bioet, Biof, EC and EC-E), the study shows the results of the assessment considering ambitious scenarios for the year 2030 in which each measure is completely implemented individually. In the real world, many other actions and strategies will take place simultaneously. This is a disadvantage for studies focussing on real scenarios; however, it can be an advantage for the analysis of strategies, since their impacts are isolated and can be quantified. Beyond the level of ambition of the scenarios, some details of the design of the strategies must be considered. We assume that the total fleet of vehicles is the same as for the reference year (year 2017), in order to be able to make the substitutions. The proportion by type of vehicle and fuel 
has been also assumed to be constant (same as the year 2017) for BioEt and Biof scenarios. When comparing results, note that, in each scenario, a different number of vehicles is substituted (i.e., vkm), and each scenario includes a different contribution of renewable energy. While, in the BioEt scenarios, the substitution of fuel represents $34 \%$ of total vkm, in the Biof scenario, it is $98 \%$. The EC scenarios represent a substitution of $82 \%$ of the $\mathrm{vkm}$ (passenger cars). Therefore, the measure affecting the highest share of road transport expressed as use (vkm), which is Biof, would achieve the lowest benefit in terms of air pollution and avoided mortality.

With regards to the exposure calculations, there are limitations related to the air quality model and the assumptions made for the population distribution. As well as inherent model uncertainties and simplifications used in air quality simulations, model input data, such as the emissions and meteorology, also contribute considerable uncertainty to the concentration predictions. This uncertainty has been reduced by adjusting the concentration estimates using information from the observed concentrations; however, this process itself adds uncertainty to the concentrations estimated for the scenarios through the assumption that model biases are proportional to the concentrations. The use of a spatial resolution of $0.1^{\circ} \times 0.1^{\circ}$ could lead to errors in the exposure estimates, since the real spatial variability in concentrations is not represented, especially in urban areas, and neither is the real population density. Previous studies have tried to quantify the differences due to the spatial resolution for different pollutants, regions, model parameters, etc. [84-87], and one study even found that a lower resolution of $12 \mathrm{~km}$ performed better than a higher resolution assessment $(4 \mathrm{~km})$ [88]. From the point of view of exposure, the population is considered to be exposed to the given concentration of pollutants according to the place where they live (settlements and inhabitants' data were used to allocate the population along the domain). This is not true, since people travel, move, commute, etc., on a daily basis. For the large domain and spatial resolution used in this study, this assumption is reasonable. By contrast, the study does consider changes in the population by applying growing rates, through NUTS3, in the scenarios (including the baseline). A sensitivity analysis of the results for avoided mortality compared with a reference scenario with and without population projections is shown in Table 7. This way, the impact of the growth of population on the effect of the strategies can be assessed. When the population for the year 2017 is used for the baseline, the potential impact of the measures is lower since the larger population in the scenarios for 2030 leads to an increase in mortality; therefore, the avoided impacts are lower, thus preventing an assessment of the individual effect of the strategies.

Table 7. Sensitivity analysis of the avoided mortality due to air pollution exposure with and without taking into account population growth for 2030 in the reference scenario.

\begin{tabular}{ccccc}
\hline \% Reduction & BioEt & Biof & EC & EC-A \\
\hline Reference scenario with Pop. Proj. year 2030 & $0.52 \%$ & $0.30 \%$ & $14.45 \%$ & $15.90 \%$ \\
Reference scenario with Pop. 2017 & $7.93 \%$ & $8.2 \%$ & $7.19 \%$ & $8.76 \%$ \\
\hline
\end{tabular}

The methods used for the HIA and external cost estimations also have limitations. HIA is based on CRFs, which are expressed in RR with confidence intervals collected from epidemiological studies. We have used the most widely recommended CRFs for policy support, as is explained in a recent analysis [37]. The valuation of external costs has been carried out using recognised data sources and adapting as much as possible to Spanish conditions (VSL value has been adapted to Spain considering the national income and currency value of 2019). Although the external costs should be considered as underestimates since not all associated impacts are taken into account (e.g., impacts to biodiversity, materials and crops at the local and regional level or the impacts of noise or accidents), this study provides useful information that can be taken into account when evaluating transport policies for the transition to a more sustainable system. 


\section{Conclusions}

In this study, we have assessed the impact on air quality and the associated avoided mortality of four policy measures to decarbonize the Spanish transport sector based on biofuel blending and the adoption of electric vehicles. The results should be interpreted taking into account the limitations of the study related to the simplifications in the scenario design, model assumptions and methodologies applied.

The results of the air quality modeling show that, in general, the largest improvements in air quality result from the scenarios with the largest emission reductions. Large reductions in $\mathrm{NO}_{\mathrm{x}}$ emissions in the scenarios for the adoption of electric cars are estimated to lead to large reductions in concentrations of $\mathrm{NO}_{2}$ and, to a lesser extent, $\mathrm{O}_{3}$. Substantial reductions in particulate matter (PM) concentrations are also estimated for the electric car scenarios, although, in the case of the scenario that takes into account the additional electricity demand and changes in the energy mix for 2030 (EC-E), these reductions are the result of lower SOx emissions leading to less formation of secondary particles. By contrast, the biofuel scenarios are expected to increase PM concentrations in some regions as a result of increased $\mathrm{NH}_{3}$ emissions (more formation of secondary particles). The study also highlights the importance of the location of the emission reductions, since a reduction in $\mathrm{NO}_{\mathrm{x}}$ emissions from electricity generation (local reduction in areas with low population density) has a much smaller benefit in terms of improvements in air quality and health impacts than a similar emission reduction applied to emissions from passenger cars (reduction across the whole domain).

The results of the health impact assessment show an overall positive impact on health associated with the biofuel scenario (Biof) (although there are negative impacts related to PM exposure in certain areas) and a great benefit associated with the scenario that maximizes electric car use. $\mathrm{NO}_{\mathrm{x}}$ emission reductions (mainly through the introduction of electric vehicles) lead to the largest reductions in premature deaths. Also, the reduction in $\mathrm{PM}_{2.5}$ is a large contributor to the reduced mortality that was predicted. The increase in electricity production required by the operation of the additional electric cars (and the associated emissions from power plants) does not preclude the benefits of this measure in terms of avoided mortality and external costs. This is partly due to the expected decarbonisation of the electricity mix in 2030. The scenario BioEt (adoption of petrol E85 for passenger cars and E10 for the remaining petrol-fueled cars) reduces mortality and external costs, driven by reductions in $\mathrm{NO}_{2}$ and ozone-related impacts, although there are increases in PM related impacts and costs. The scenario Biof (combined introduction of the measures of the scenario Bioet and B20 in all the diesel vehicles) decreases net mortality and associated costs but increases premature deaths due to PM exposure. The largest negative impacts associated with biofuels due to increased PM exposure are estimated to be in the most populated urban areas.

From the point of view of the co-benefit assessment, the GHG emission estimates and associated climate-induced damages indicate that the measures proposed in all scenarios can help to reduce externalities, even in the less beneficial Biof scenario. However, the design of policies for road transport and mobility based on the measures included in Bioet and Biof should optimize the benefits, suggesting taking special consideration of where and how biofuels can contribute to a more sustainable road sector as the population exposure is crucial. It would be better to prioritize the adoption of electric vehicles in those urban areas where biofuel measures lead to the largest increase in mortality, and foster biofuel use in areas with lower population density.

Author Contributions: Conceptualization, A.R.G., Y.L. and M.G.V.; methodology, A.R.G.; software, A.R.G., E.S. and M.G.V.; formal analysis, A.R.G., Y.L., M.G.V., M.R.T., V.G., J.L.G. and A.R.-S.; investigation, A.R.G., Y.L., M.G.V., M.R.T., V.G., J.L.G. and A.R.-S.; resources, A.R.G., Y.L. and M.G.V.; data curation, A.R.G., Y.L., M.G.V., J.L.G., F.M., E.S., M.R.T., V.G. and J.L.S.; writing-original draft preparation, A.R.G., Y.L., C.L. and M.G.V.; writing-review and editing, A.R.G., Y.L., M.G.V., C.L., J.L.S., F.M. and M.R.T.; visualization, A.R.G., J.L.G. and M.R.T.; supervision, Y.L. and M.G.V.; project 
administration, M.G.V. and J.L.S.; funding acquisition, M.G.V. and J.L.S. All authors have read and agreed to the published version of the manuscript.

Funding: This research was funded by the National Agency for Scientific Research of the Spanish Ministry of Science and Innovation, though the Retos-AIRE project (Air pollution mitigation actions for environmental policy support. Air quality multiscale modelling and evaluation of health and vegetation impacts), with grant number "RTI2018-099138-B-100".

Acknowledgments: The modelling that provides data for this study is based on data provided through collaborations with other public organizations. In this regard, we thank Tragsatec for their collaboration in estimating the emission reductions for the measures in the NAPCP and to the Ministry for the Ecological Transition and Demographic Challenge for providing data from air quality stations and information on emission reductions. We are also grateful for the services offered by the European Center for Medium-Range Weather Forecasts (ECMWF), including the provision of meteorological modelling data with thanks also to AEMET for managing access to this information. Finally, we thank the Ministry of Science and Innovation for financial support through the project Retos-AIRE (RTI2018-099138-B-100).

Conflicts of Interest: The authors declare no conflict of interest. The funders had no role in the design of the study; in the collection, analyses, or interpretation of data; in the writing of the manuscript, or in the decision to publish the results.

\section{Appendix A}

Table A1. Road transport activity data used to calculate air pollutant emissions for the 2017 baseline. Note: The values for average annual travel distance are from 2016, since these were the latest available data from the NECP.

\begin{tabular}{|c|c|c|c|}
\hline & $\begin{array}{c}\text { Fuel Use } \\
\text { (Kt Oil Equivalent) }\end{array}$ & No. of Vehicles & $\begin{array}{c}\text { Average Travel } \\
\text { Distance }\left(\mathrm{km} \mathrm{yr}^{-1}\right)\end{array}$ \\
\hline $\begin{array}{l}\text { All road transport } \\
\text { Total }\end{array}$ & $28,408.9$ & $30,841197.0$ & \\
\hline $\begin{array}{c}\text { Cars } \\
\text { Diesel } \\
\text { Biodiesel } \\
\text { Petrol } \\
\text { Bioethanol } \\
\text { LPG } \\
\text { Electric } \\
\text { CNG } \\
\text { Total }\end{array}$ & $\begin{array}{c}10,840.0 \\
489.0 \\
3641.8 \\
102.3 \\
47.2 \\
1.4 \\
265.3 \\
15,387.0\end{array}$ & $\begin{array}{c}13,611,088 \\
7,452,327 \\
209,239 \\
44,872 \\
12,170 \\
158,796 \\
21,488,491\end{array}$ & $\begin{array}{c}16,522 \\
8696 \\
8696 \\
16,522 \\
9566 \\
16,522\end{array}$ \\
\hline $\begin{array}{c}\text { Lorries } \\
\text { Diesel } \\
\text { Biodiesel } \\
\text { Petrol } \ddagger \\
\text { Bioethanol } \\
\text { Total } \\
\end{array}$ & $\begin{array}{c}7399.2 \\
320.9 \\
32.0 \\
0.9 \\
7753.1 \\
\end{array}$ & $\begin{array}{c}267,515 \\
2038 \\
57 \\
269,611 \\
\end{array}$ & $\begin{array}{l}89,742 \\
44,871 \\
44,871\end{array}$ \\
\hline $\begin{array}{c}\text { Vans } \\
\text { Diesel } \\
\text { Biodiesel } \\
\text { Petrol } \\
\text { Bioethanol } \\
\text { LPG }^{*} \\
\text { CNG \# } \\
\text { Electric } \\
\text { Total }\end{array}$ & $\begin{array}{c}2830.3 \\
133.1 \\
202.1 \\
5.3 \\
415.2 \\
11.3 \\
1.4 \\
3598.6\end{array}$ & $\begin{array}{c}3,411,130 \\
310,804 \\
8120 \\
594,849 \\
6956 \\
4986 \\
4,336,844\end{array}$ & $\begin{array}{c}12,671 \\
8448 \\
8448 \\
12,671 \\
12,671 \\
8448\end{array}$ \\
\hline $\begin{array}{c}\text { Urban and regional } \\
\text { buses } \\
\text { Diesel } \\
\text { Biodiesel } \\
\end{array}$ & 912.7 & 55,045 & 6335 \\
\hline
\end{tabular}


Table A1. Cont.

\begin{tabular}{|c|c|c|c|}
\hline & $\begin{array}{c}\text { Fuel Use } \\
\text { (Kt Oil Equivalent) }\end{array}$ & No. of Vehicles & $\begin{array}{c}\text { Average Travel } \\
\text { Distance }\left(\mathrm{km} \mathrm{yr}^{-1}\right)\end{array}$ \\
\hline $\begin{array}{c}\text { Petrol } \\
\text { Bioethanol }\end{array}$ & 40.4 & & 6335 \\
\hline $\mathrm{CNG}$ & 11.3 & 619 & 6335 \\
\hline Electric & 0.9 & 123 & 6335 \\
\hline Total & 965.2 & 55,787 & \\
\hline \multicolumn{4}{|c|}{$\begin{array}{c}\text { Motorcycles and } \\
\text { small electric vehicles }\end{array}$} \\
\hline Diesel † & 6.5 & 54.474 & 48,562 \\
\hline Biodiesel & 0.3 & $54,4 / 4$ & 48,562 \\
\hline Petrol & 678.6 & $4,493,535$ & 19,425 \\
\hline Bioethanol & 19.1 & 126,449 & 19,425 \\
\hline Electric & 0.5 & 16,005 & 48,562 \\
\hline Total & 705.0 & $4,690,464$ & \\
\hline
\end{tabular}

Table A2. Spanish annual pollutant emissions (tonnes) for the emission sectors SNAP 1 and SNAP 7 and the total anthropogenic emissions (sum of SNAP 1 to SNAP 10) used in the air quality simulations.

\begin{tabular}{cccccccc}
\hline & Scenario & $\mathbf{N H}_{\mathbf{3}}$ & $\mathbf{N M V O C}$ & $\mathbf{N O}_{\mathbf{x}}$ & $\mathbf{P M}_{\mathbf{2 . 5}}$ & $\mathbf{P M}_{\mathbf{1 0}}$ & $\mathbf{S O}_{\mathbf{x}}$ \\
\hline $\begin{array}{c}\text { SNAP 1 } \\
\text { (Combustion in the } \\
\text { production and }\end{array}$ & Baseline 2017 & 1317 & 6324 & 100,744 & 4940 & 6485 & 90,372 \\
transformation of energy) & & & & & & \\
SNAP 7 & EC-E & 1317 & 5565 & 33,246 & 11,412 & 12,633 & 6326 \\
(Road transport) & Baseline 2017 & 2439 & 22,354 & 244,713 & 10,009 & 13,999 & 394 \\
& BioEt & 7536 & 12,295 & 239,819 & 9909 & 13,860 & 450 \\
& Biof & 7536 & 11,401 & 244,713 & 8808 & 12,319 & 446 \\
Total anthropogenic emissions & EC and EC-E & 683 & 11,758 & 167,629 & 6729 & 9411 & 188 \\
& Baseline 2017 & 518,192 & 618,717 & 739,031 & 112,771 & 180,240 & 220,275 \\
& BioEt & 523,290 & 608,658 & 734,136 & 112,684 & 180,101 & 220,330 \\
& Biof & 523,290 & 607,764 & 739,031 & 111,720 & 178,560 & 220,326 \\
& EC & 516,437 & 608,121 & 661,946 & 109,491 & 175,653 & 220,068 \\
& EC-E & 516,437 & 607,362 & 594,447 & 115,963 & 181,802 & 136,023 \\
\hline
\end{tabular}

Table A3. Changes with respect to the baseline in the Spanish annual pollutant emissions (tonnes) for the emission sectors SNAP 1 and SNAP 7 and the total anthropogenic emissions (sum of SNAP 1 to SNAP 10) used in the air quality simulations.

\begin{tabular}{|c|c|c|c|c|c|c|c|}
\hline & Scenario & $\mathrm{NH}_{3}$ & NMVOC & NOx & $\mathbf{P M}_{2.5}$ & $\mathbf{P M}_{10}$ & SOx \\
\hline $\begin{array}{c}\text { SNAP 1 } \\
\text { (Combustion in the } \\
\text { production and } \\
\text { transformation of energy) }\end{array}$ & EC-E & -- & $-12 \%$ & $-67 \%$ & $+131 \%$ & $+95 \%$ & $-93 \%$ \\
\hline $\begin{array}{c}\text { SNAP 7 } \\
\text { (Road transport) }\end{array}$ & BioEt & $+209 \%$ & $-45 \%$ & $-2 \%$ & $-1 \%$ & $-1 \%$ & $+14 \%$ \\
\hline Total anthropogenic emissions & $\begin{array}{c}\text { Biof } \\
\text { EC and EC-E } \\
\text { BioEt } \\
\text { Biof } \\
\text { EC } \\
\text { EC-E }\end{array}$ & $\begin{array}{l}+209 \% \\
-72 \% \\
+1 \% \\
+1 \% \\
-- \\
--\end{array}$ & $\begin{array}{l}-49 \% \\
-47 \% \\
-2 \% \\
-2 \% \\
-2 \% \\
-2 \%\end{array}$ & $\begin{array}{c}-- \\
-31 \% \\
-1 \% \\
-- \\
-10 \% \\
-20 \%\end{array}$ & $\begin{array}{c}-12 \% \\
-33 \% \\
-0.1 \% \\
-0.9 \% \\
-3 \% \\
+3 \%\end{array}$ & $\begin{array}{c}-12 \% \\
-33 \% \\
-0.1 \% \\
-0.9 \% \\
-3 \% \\
+1 \%\end{array}$ & $\begin{array}{c}+13 \% \\
-52 \% \\
+0.03 \% \\
+0.02 \% \\
-0.09 \% \\
-38 \%\end{array}$ \\
\hline
\end{tabular}




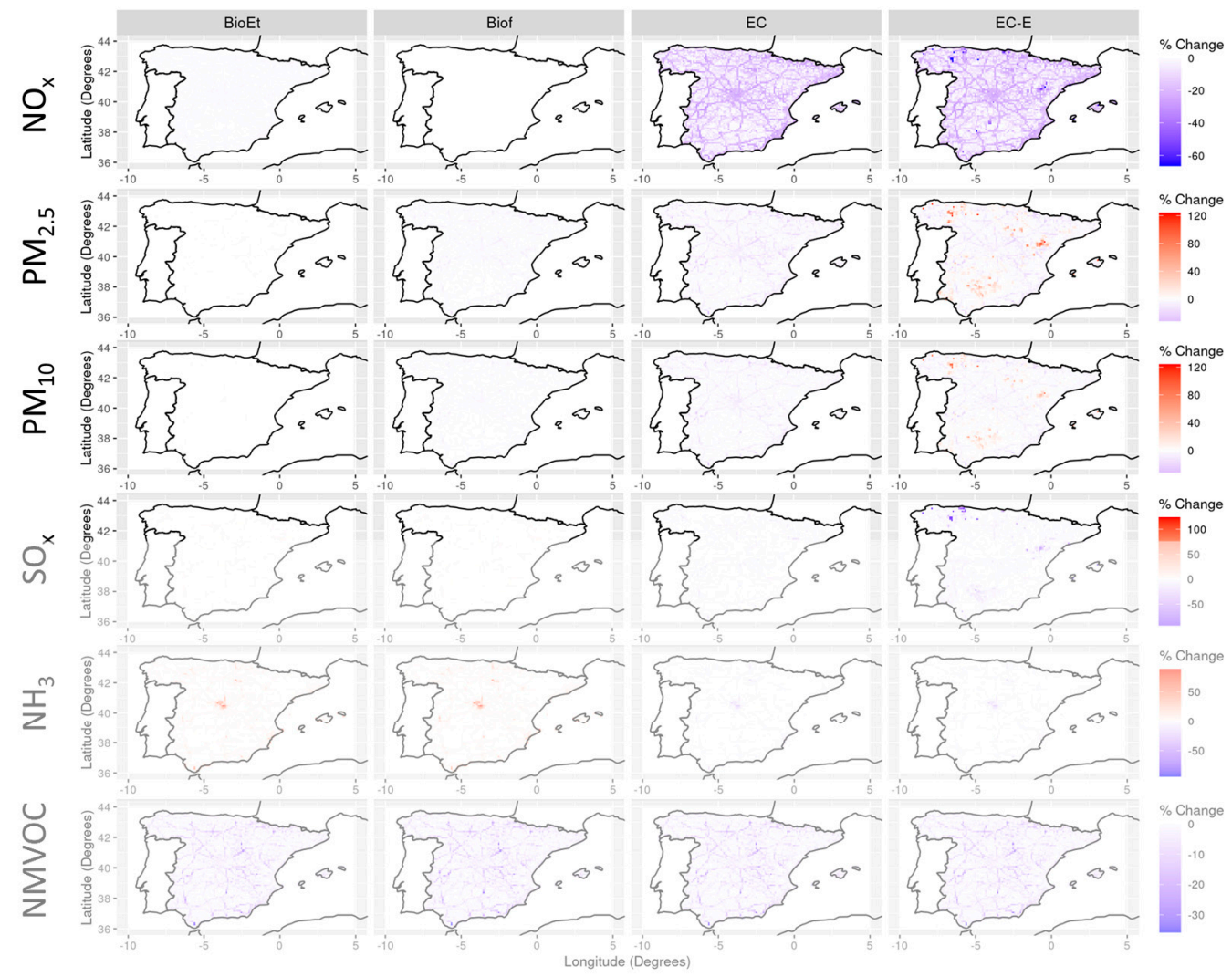

Figure A1. Maps of emission changes (\%) with respect to the baseline (2017).

Table A4. Descriptive table of data and results on population, pollutants concentration and mortality along the domain (cells values analysis) including the mean, maximum and minimum values.

\begin{tabular}{|c|c|c|c|c|c|c|c|c|c|c|c|}
\hline \multirow[t]{3}{*}{ Scenario } & \multirow[t]{3}{*}{ Descriptive } & \multirow{2}{*}{$\begin{array}{c}\text { Population } \\
\text { All Ages }\end{array}$} & \multicolumn{4}{|c|}{ Pollution } & \multicolumn{5}{|c|}{ Mortality } \\
\hline & & & $\begin{array}{c}\mathrm{NO}_{2} \\
\text { Annual } \\
\text { Mean }\end{array}$ & $\begin{array}{c}\mathbf{P M}_{2.5} \\
\text { Annual } \\
\text { Mean }\end{array}$ & $\begin{array}{c}\mathbf{P M}_{10} \\
\text { Annual } \\
\text { Mean }\end{array}$ & $\begin{array}{l}\text { SOMO35 } \\
\text { (O3) }\end{array}$ & $\mathrm{NO}_{2}$ & $\mathrm{NO}_{2} \mathrm{ac}$ & $\mathbf{P M}_{2.5}$ & $\mathbf{P M}_{10}$ & $\mathrm{O}_{3}$ \\
\hline & & Inhabitants & $\left(\mu \mathrm{g} \cdot \mathrm{m}^{-3}\right)$ & $\left(\mu \mathrm{g} \cdot \mathrm{m}^{-3}\right)$ & $\left(\mu \mathrm{g} \cdot \mathrm{m}^{-3}\right)$ & (ppb·Days) & $\begin{array}{c}\text { Premature } \\
\text { Deaths } \\
(>30 \\
\text { Years })\end{array}$ & $\begin{array}{l}\text { Premature } \\
\text { Deaths }\end{array}$ & $\begin{array}{l}\text { Premature } \\
\text { Deaths }\end{array}$ & $\begin{array}{l}\text { Premature } \\
\text { Deaths }\end{array}$ & $\begin{array}{l}\text { Premature } \\
\text { Infant } \\
\text { Deaths }\end{array}$ \\
\hline \multirow{4}{*}{ REF } & Mean & 1977.34 & 1.59 & 2.06 & 3.85 & 1802.67 & 0.62 & 0.00 & 1.43 & 0.00 & 0.13 \\
\hline & Max & $1,237,053.16$ & 46.18 & 19.38 & 36.02 & $14,110.00$ & 1388.55 & 3.72 & 1019.18 & 1.26 & 64.83 \\
\hline & Min & 0.00 & 0.00 & 0.00 & 0.00 & 0.00 & 0.00 & 0.00 & 0.00 & 0.00 & 0.00 \\
\hline & Mean & 2105.28 & 1.58 & 2.06 & 3.85 & 1799.19 & 0.60 & 0.00 & 1.44 & 0.00 & 0.12 \\
\hline \multirow[t]{3}{*}{ BioEt } & Max & $1,341,460.00$ & 45.96 & 19.37 & 36.04 & $14,100.00$ & 1373.09 & 3.68 & 1031.38 & 1.26 & 64.75 \\
\hline & Min & 0.00 & 0.00 & 0.00 & 0.00 & 0.00 & 0.00 & 0.00 & 0.00 & 0.00 & 0.00 \\
\hline & Mean & 2105.28 & 1.60 & 2.05 & 3.84 & 1800.82 & 0.62 & 0.00 & 1.42 & 0.00 & 0.12 \\
\hline \multirow[t]{3}{*}{ Biof } & $\operatorname{Max}$ & $1,341,460.00$ & 46.16 & 19.33 & 35.82 & $14,097.44$ & 1387.45 & 3.72 & 1008.19 & 1.25 & 64.57 \\
\hline & Min & 0.00 & 0.00 & 0.00 & 0.00 & 0.00 & 0.00 & 0.00 & 0.00 & 0.00 & 0.00 \\
\hline & Mean & 2105.28 & 1.39 & 1.98 & 3.75 & 1771.36 & 0.37 & 0.00 & 1.36 & 0.00 & 0.12 \\
\hline \multirow[t]{3}{*}{$\mathrm{EC}$} & Max & $1,341,460.00$ & 43.90 & 19.04 & 35.03 & $14,044.77$ & 1144.96 & 3.07 & 933.74 & 1.20 & 67.14 \\
\hline & Min & 0.00 & 0.00 & 0.00 & 0.00 & 0.00 & 0.00 & 0.00 & 0.00 & 0.00 & 0.00 \\
\hline & Mean & 2105.28 & 1.36 & 1.90 & 3.63 & 1753.95 & 0.37 & 0.00 & 1.33 & 0.00 & 0.12 \\
\hline \multirow[t]{2}{*}{ EC-E } & Max & $1,341,460.00$ & 43.81 & 18.13 & 34.88 & $13,966.01$ & 1137.78 & 3.07 & 927.63 & 1.19 & 66.66 \\
\hline & Min & 0.00 & 0.00 & 0.00 & 0.00 & 0.00 & 0.00 & 0.00 & 0.00 & 0.00 & 0.00 \\
\hline
\end{tabular}

\section{References}

1. European Environment Agency. Transport. Available online: https://www.eea.europa.eu/themes/transport/ (accessed on 21 July 2021).

2. Mcadam, K.; Aubin, P.L. Effective Interventions to Mitigate Adverse Human Health Effects from Transportation-Related Air and Noise Pollution A Rapid Review. Available online: https:/ /www.peelregion.ca/health/library/pdf/Rapid-Review-TRAP\%20 Mitigation.pdf (accessed on 21 July 2021). 
3. MITECO. Plan Nacional Integrado de Energía y Clima 2021-2030. Available online: https://www.miteco.gob.es/images/es/ pnieccompleto_tcm30-508410.pdf (accessed on 20 October 2021).

4. MITERD. I Programa Nacional de Control de la Contaminación Atmosférica. Available online: https://www.miteco. gob.es/es / calidad-y-evaluacion-ambiental/temas/atmosfera-y-calidad-del-aire/primerpncca_2019_tcm30-502010.pdf (accessed on 21 July 2021).

5. OECD. The Economic Consequences of Outdoor Air Pollution; OECD Publishing: Paris, France, 2016.

6. Hunt, A.; Ferguson, J.; Hurley, F.; Searl, A. Social Costs of Morbidity Impacts of Air Pollution; OECD Publishing: Paris, France, 2016.

7. OCDE. The Cost of Air Pollution; OECD Publishing: Paris, France, 2014.

8. Korzhenevych, A.; Dehnen, N.; Bröcker, J.; Holtkamp, M.; Meier, H.; Gibson, G.; Varma, A.; Cox, V. Update of the Handbook on External Costs of Transport; Final Report Ricardo-AEA/R/ ED57769; Ricardo-AEA: London, UK, 2014.

9. Im, U.; Brandt, J.; Geels, C.; Hansen, K.M.; Christensen, J.H.; Andersen, M.S.; Solazzo, E.; Kioutsioukis, I.; Alyuz, U.; Balzarini, A.; et al. Assessment and economic valuation of air pollution impacts on human health over Europe and the United States as calculated by a multi-model ensemble in the framework of AQMEII3. Atmos. Chem. Phys. 2018, 18, 5967-5989. [CrossRef]

10. Román-Collado, R.; Jiménez de Reyna, J. The economic benefits of fulfilling the World Health Organization's limits for particulates: A case study in Algeciras Bay (Spain). J. Air Waste Manag. Assoc. 2019, 69, 438-449. [CrossRef]

11. Stern, N. The economics of climate change. In Proceedings of the American Economic Review, New Orleans, LA, USA, 4-6 January 2008; Volume 98, pp. 1-37.

12. Sanderson, B.M.; O'Neill, B.C. Assessing the costs of historical inaction on climate change. Sci. Rep. 2020, 10, 1-12. [CrossRef] [PubMed]

13. MCKinsey\&Company. Pathways to a Low-Carbon Economy: We Consider Alternative History Scenarios in Which Explicit Climate Mitigation Begins before the Present Day, Estimating the Total Costs to Date of Delayed Action. Considering a 2(1.5) Degree Celsius Stabilization Target. Available online: https:/ / www.cbd.int/financial/doc/Pathwaystoalowcarboneconomy.pdf (accessed on 21 July 2021).

14. Edenhofer, O.; Sokona, Y.; Minx, J.C.; Farahani, E.; Kadner, S.; Seyboth, K.; Adler, A.; Baum, I.; Brunner, S.; Kriemann, B.; et al. AR5 Climate Change 2014: Mitigation of Climate Change; Cambridge University Press: New York, NY, USA, 2014.

15. Sampedro, J.; Smith, S.J.; Arto, I.; González-Eguino, M.; Markandya, A.; Mulvaney, K.M.; Pizarro-Irizar, C.; Van Dingenen, R. Health co-benefits and mitigation costs as per the Paris Agreement under different technological pathways for energy supply. Environ. Int. 2020, 136, 105513. [CrossRef]

16. Holland, M.R. The Co-Benefits of Different Ambition Levels for Greenhouse Gas Abatement in the EU by 2020. Available online: https: / / docplayer.net/176646461-The-co-benefits-to-health-of-a-strong-eu-climate-change-policy.html (accessed on 21 July 2021).

17. Karlsson, M.; Alfredsson, E.; Westling, N. Climate policy co-benefits: A review. Clim. Policy 2020, 20, 292-316. [CrossRef]

18. Vandyck, T.; Keramidas, K.; Kitous, A.; Spadaro, J.V.; Van Dingenen, R.; Holland, M.; Saveyn, B. Air quality co-benefits for human health and agriculture counterbalance costs to meet Paris Agreement pledges. Nat. Commun. 2018, 9, 1-11. [CrossRef] [PubMed]

19. Scovronick, N.; Budolfson, M.; Dennig, F.; Errickson, F.; Fleurbaey, M.; Peng, W.; Socolow, R.H.; Spears, D.; Wagner, F. The impact of human health co-benefits on evaluations of global climate policy. Nat. Commun. 2019, 10, 1-12. [CrossRef] [PubMed]

20. Xie, Y.; Dai, H.; Xu, X.; Fujimori, S.; Hasegawa, T.; Yi, K.; Masui, T.; Kurata, G. Co-benefits of climate mitigation on air quality and human health in Asian countries. Environ. Int. 2018, 119, 309-318. [CrossRef] [PubMed]

21. Markandya, A.; Sampedro, J.; Smith, S.; Van Dingenen, R.; Pizarro-Irizar, C.; Arto, I. Health co-benefits from air pollution and mitigation costs of the Paris Agreement: A modelling study. Lancet. Planet. Health 2018, 2, e126-e133. [CrossRef]

22. Pascal, M.; Corso, M.; Chanel, O.; Declercq, C.; Badaloni, C.; Cesaroni, G.; Henschel, S.; Meister, K.; Haluza, D.; MartinOlmedo, P.; et al. Assessing the public health impacts of urban air pollution in 25 European cities: Results of the Aphekom project. Sci. Total Environ. 2013, 449, 390-400. [CrossRef] [PubMed]

23. Izquierdo, R.; García Dos Santos, S.; Borge, R.; Paz, D.; de la Sarigiannis, D.; Gotti, A.; Boldo, E. Health impact assessment by the implementation of Madrid City air-quality plan in 2020. Environ. Res. 2020, 183, 109021. [CrossRef]

24. Bell, M.L.; Davis, D.L.; Gouveia, N.; Borja-Aburto, V.H.; Cifuentes, L.A. The avoidable health effects of air pollution in three Latin American cities: Santiago, São Paulo, and Mexico City. Environ. Res. 2006, 100, 431-440. [CrossRef]

25. CE Delft. Health Costs of Air Pollution in European Cities and the Linkage with Transport; CE Delft: Delft, The Netherlands, 2020.

26. Hamilton, I.; Kennard, H.; McGushin, A.; Höglund-Isaksson, L.; Kiesewetter, G.; Lott, M.; Milner, J.; Purohit, P.; Rafaj, P.; Sharma, R.; et al. The public health implications of the Paris Agreement: A modelling study. Lancet Planet. Health 2021, 5, e74-e83. [CrossRef]

27. Gallagher, C.L.; Holloway, T. Integrating Air Quality and Public Health Benefits in U.S. Decarbonization Strategies. Front. Public Health 2020, 8, 520. [CrossRef]

28. Jiang, P.; Chen, Y.; Geng, Y.; Dong, W.; Xue, B.; Xu, B.; Li, W. Analysis of the co-benefits of climate change mitigation and air pollution reduction in China. J. Clean. Prod. 2013, 58, 130-137. [CrossRef]

29. Kim, S.E.; Xie, Y.; Dai, H.; Fujimori, S.; Hijioka, Y.; Honda, Y.; Hashizume, M.; Masui, T.; Hasegawa, T.; Xu, X.; et al. Air quality co-benefits from climate mitigation for human health in South Korea. Environ. Int. 2020, 136, 105507. [CrossRef] 
30. Peng, W.; Dai, H.; Guo, H.; Purohit, P.; Urpelainen, J.; Wagner, F.; Wu, Y.; Zhang, H. The Critical Role of Policy Enforcement in Achieving Health, Air Quality, and Climate Benefits from India's Clean Electricity Transition. Environ. Sci. Technol. 2020, 54, 11720-11731. [CrossRef]

31. Thambiran, T.; Diab, R.D. Air quality and climate change co-benefits for the industrial sector in Durban, South Africa. Energy Policy 2011, 39, 6658-6666. [CrossRef]

32. Mittal, S.; Hanaoka, T.; Shukla, P.R.; Masui, T. Air pollution co-benefits of low carbon policies in road transport: A sub-national assessment for India. Environ. Res. Lett. 2015, 10, 085006. [CrossRef]

33. Xia, T.; Nitschke, M.; Zhang, Y.; Shah, P.; Crabb, S.; Hansen, A. Traffic-related air pollution and health co-benefits of alternative transport in Adelaide, South Australia. Environ. Int. 2015, 74, 281-290. [CrossRef]

34. Sarigiannis, D.A.; Kontoroupis, P.; Nikolaki, S.; Gotti, A.; Chapizanis, D.; Karakitsios, S. Benefits on public health from transportrelated greenhouse gas mitigation policies in Southeastern European cities. Sci. Total Environ. 2017, 579, 1427-1438. [CrossRef]

35. ITF/OCDE. Transport Climate Action Directory I Internatiopnal Transport Forum. Available online: https://www.itf-oecd.org/ tcad (accessed on 26 July 2021).

36. Vivanco, M.G.; Garrido, J.L.; Martín, F.; Theobald, M.R.; Gil, V.; Santiago, J.-L.; Lechón, Y.; Gamarra, A.R.; Sánchez, E.; Alberto, A.; et al. Assessment of the effects of the spanish national air pollution control programme on air quality. Atmosphere 2021, 12, 158. [CrossRef]

37. Gamarra, A.R.; Lechón, Y.; Vivanco, M.G.; Garrido, J.L.; Martín, F.; Sánchez, E.; Theobald, M.R.; Gil, V.; Santiago, J.L. Benefit Analysis of the 1st Spanish Air Pollution Control Programme on Health Impacts and Associated Externalities. Atmosphere 2020, 12, 32. [CrossRef]

38. European Union. Directive (EU) 2018/2001 of the European Parliement and of the Council of 11 December 2018 on the Promotion of the Use of Energy from Renewable Sources. Available online: https:/ / eur-lex.europa.eu/eli/dir/2018/2001/oj (accessed on 21 July 2021).

39. European Union. Proposal for a firective of the European Parliament and of the Council Amending Directive (EU) 2018/2001 of the European Parliament and of the Council, Regulation (EU) 2018/1999 of the European Parliament and of the Council and Directive 98/70/EC of the European Parliament and of the Council as Regards the Promotion of Energy from Renewable Sources COM/2021/557 Final; European Parliament and of the Council: Brussels, Belgium, 2021.

40. Alalwan, H.A.; Alminshid, A.H.; Aljaafari, H.A.S. Promising evolution of biofuel generations. Subject review. Renew. Energy Focus 2019, 28, 127-139. [CrossRef]

41. Ministerio para la Transición Ecológica y el Reto Demográfico. Real Decreto 205/2021, de 30 de Marzo, por el que se modifica el Real Decreto 1085/2015, de 4 de Diciembre, de Fomento de los Biocarburantes, y se Regulan los Objetivos de venta o Consumo de Biocarburantes para los años 2021 y 2022. Available online: https:/ / www.boe.es/diario_boe/txt.php?id=BOE-A-2021-5034 (accessed on 21 July 2021).

42. EMEP. 1.A.1 Energy industries. In EMEP/EEA Air Pollutant Emission Inventory Guidebook 2019. Available online: https: //www.eea.europa.eu/publications / emep-eea-guidebook-2019 (accessed on 21 July 2021).

43. EUSTAT Definition. SNAP Nomenclature. Available online: https://en.eustat.eus/documentos/elem_13173/definicion.html (accessed on 23 August 2021).

44. Timmers, V.R.J.H.; Achten, P.A.J. Non-exhaust PM emissions from electric vehicles. Atmos. Environ. 2016, 134, 10-17. [CrossRef]

45. Ministerio para la Transición Ecológica y el Reto Demográfico. Libro de la Energía en España 2018; Ministerio para la Transición Ecológica y el Reto Demográfico: Madrid, Spain, 2018.

46. Menut, L.; Bessagnet, B.; Khvorostyanov, D.; Beekmann, M.; Blond, N.; Colette, A.; Coll, I.; Curci, G.; Foret, G.; Hodzic, A.; et al. Chimere 2013: A model for regional atmospheric composition modelling. Geosci. Model Dev. 2013, 6, 981-1028. [CrossRef]

47. Pirovano, G.; Balzarini, A.; Bessagnet, B.; Emery, C.; Kallos, G.; Meleux, F.; Mitsakou, C.; Nopmongcol, U.; Riva, G.M.; Yarwood, G. Investigating impacts of chemistry and transport model formulation on model performance at European scale. Atmos. Environ. 2012, 53, 93-109. [CrossRef]

48. Vivanco, M.G.; Palomino, I.; Vautard, R.; Bessagnet, B.; Martín, F.; Menut, L.; Jiménez, S. Multi-year assessment of photochemical air quality simulation over Spain. Environ. Model. Softw. 2009, 24, 63-73. [CrossRef]

49. Vivanco, M.G.; Palomino, I.; Martín, F.; Palacios, M.; Jorba, O.; Jiménez, P.; Baldasano, J.M.; Azula, O. An evaluation of the performance of the Chimere model over spain using meteorology from MM5 and WRF models. In Proceedings of the Lecture Notes in Computer Science (Including Subseries Lecture Notes in Artificial Intelligence and Lecture Notes in Bioinformatics), Seoul, Korea, 29 June-2 July 2009; Springer: Berlin/Heidelberg, Germany, 2009; Volume 5592 LNCS, pp. 107-117.

50. Vivanco, M.G.; Correa, M.; Azula, O.; Palomino, I.; Martín, F. Influence of model resolution on ozone predictions over Madrid Area (Spain). In Proceedings of the Lecture Notes in Computer Science (Including Subseries Lecture Notes in Artificial Intelligence and Lecture Notes in Bioinformatics), Perugia, Italy, 30 June-3 July 2008; Springer: Berlin/Heidelberg, Germany, 2008; Volume 5072 LNCS, pp. 165-178.

51. Bessagnet, B.; Pirovano, G.; Mircea, M.; Cuvelier, C.; Aulinger, A.; Calori, G.; Ciarelli, G.; Manders, A.; Stern, R.; Tsyro, S.; et al. Presentation of the EURODELTA III intercomparison exercise-evaluation of the chemistry transport models' performance on criteria pollutants and joint analysis with meteorology. Atmos. Chem. Phys. 2016, 16, 12667-12701. [CrossRef]

52. European Environment Agengy. SOMO35—European Environment Agency. Available online: https://www.eea.europa.eu/ help/glossary / eea-glossary/somo35 (accessed on 23 September 2020). 
53. Holland, M. Implementation of the HRAPIE Recommendations for European Air Pollution CBA Work; International Institute for Applied Systems Analysis: Laxenburg, Austria, 2014.

54. Soares, J.; Horálek, J.; González, A.; Ortiz Guerreiro, C.; Gsella, A. Health Risk Assessment of Air Pollution in Europe Methodology Description and 2017 Results-Eionet Report-ETC/ATNI 2019/13; European Enviroment Agency: Luxembourg, 2019.

55. WHO. Health Risks of Air Pollution in Europe-HRAPIE Project, Recommendations for Concentration-Response Functions for Cost-Benefit Analysis of Particulate Matter, Ozone and Nitrogen Dioxide; WHO: Copenhaga, Denmark, 2013.

56. WHO. Review of Evidence on Health Aspects of Air Pollution-REVIHAAP Project Technical Report; WHO: Copenhaga, Denmark, 2013.

57. Hoek, G.; Krishnan, R.M.; Beelen, R.; Peters, A.; Ostro, B.; Brunekreef, B.; Kaufman, J.D. Long-term air pollution exposure and cardio-respiratory mortality: A review. Environ. Health A Glob. Access Sci. Source 2013, 12, 43. [CrossRef]

58. Samoli, E.; Aga, E.; Touloumi, G.; Nisiotis, K.; Forsberg, B.; Lefranc, A.; Pekkanen, J.; Wojtyniak, B.; Schindler, C.; Niclu, E.; et al. Short-term effects of nitrogen dioxide on mortality: An analysis within the APHEA project. Eur. Respir. J. 2006, 27, 1129-1137. [CrossRef]

59. Katsouyanni, K.; Samet, J.M.; Ross Anderson, H.; Atkinson, R.; Le Tertre, A.; Medina, S.; Samoli, E.; Touloumi, G.; Burnett, R.T.; Krewski, D.; et al. Air Pollution and Health: A European and North American Approach (APHENA); Health Effects Institute: Boston, MA, USA, 2009.

60. Gryparis, A.; Forsberg, B.; Katsouyanni, K.; Analitis, A.; Touloumi, G.; Schwartz, J.; Samoli, E.; Medina, S.; Anderson, H.R.; Niciu, E.M.; et al. Acute Effects of Ozone on Mortality from the "Air Pollution and Health: A European Approach" project. Am. J. Respir. Crit. Care Med. 2004, 170, 1080-1087. [CrossRef]

61. Woodruff, T.J.; Grillo, J.; Schoendorf, K.C. The relationship between selected causes of postneonatal infant mortality and particulate air pollution in the United States. Environ. Health Perspect. 1997, 105, 608-612. [CrossRef]

62. IGN Centro Nacional de Información Geográfica. (CNIG)-Centro de Descargas del CNIG. Available online: http: / / centrodedescargas.cnig.es/CentroDescargas / catalogo.do?Serie=CAANE (accessed on 28 September 2020).

63. Instituto National de Estadistica. Demografía y Población: Cifras de Población y Censos Demográficos, Proyecciones de Población, Resultados. Available online: https:/ / www.ine.es / dyngs/INEbase/es / operacion.htm?c=Estadistica_C\&cid=1254736176953\& menu=resultados\&idp=1254735572981 (accessed on 28 September 2020).

64. European Union. Statistical Regions in the European Union and Partner Countries; European Union: Bruxelles, Belgium, 2020.

65. Schucht, S.; Colette, A.; Rao, S.; Holland, M.; Schöpp, W.; Kolp, P.; Klimont, Z.; Bessagnet, B.; Szopa, S.; Vautard, R.; et al. Moving towards ambitious climate policies: Monetised health benefits from improved air quality could offset mitigation costs in Europe. Environ. Sci. Policy 2015, 50, 252-269. [CrossRef]

66. Science Communication Unit, University of the West of England. Science for Environment Policy. What Are the Health Costs of Environmental Pollution? Science Communication Unit, University of the West of England: Bristol, UK, 2018.

67. Yin, H.; Brauer, M.; Zhang, J.; Cai, W.; Navrud, S.; Burnett, R.; Howard, C.; Deng, Z.; Kammen, D.; Schellnhuber, H.J.; et al. Global Economic Cost of Deaths Attributable to Ambient Air Pollution: Disproportionate Burden on the Ageing Population. medRxiv 2020, 2020.04.28.20083576. [CrossRef]

68. Viscusi, W.K. Best Estimate Selection Bias in the Value of a Statistical Life. J. Benefit-Cost Anal. 2018, 9, 285-304. [CrossRef]

69. Viscusi, W.K.; Masterman, C.J. Income Elasticities and Global Values of a Statistical Life. J. Benefit Cost Anal 2017, 8, 226-250. [CrossRef]

70. OECD. Mortality Risk Valuation in Environment, Health and Transport Policies; Organisation for Economic Cooperation and Development (OECD): Paris, France, 2012; Volume 9789264130.

71. Roy, R.; Braathen, N.A. The Rising Cost of Ambient Air Pollution thus far in the 21st Century: Results from the BRIICS and the OECD Countries; OECD: Paris, France, 2017.

72. INE. Cálculo de variaciones del Indice de Precios de Consumo. Available online: https://www.ine.es/varipc/verVariaciones.do? idmesini=1\&anyoini=2005\&idmesfin=1\&anyofin=2019\&ntipo=1\&enviar=Calcular (accessed on 28 September 2020).

73. OECD. Recommended Value of a Statistical Life Numbers for Policy Analysis. In Mortality Risk Valuation in Environment, Health and Transport Policies; OECD Publishing: Paris, France, 2012; pp. 125-136.

74. CNMC. Dirección de Energía. In Estadística de Biocarburantes. Available online: https://www.cnmc.es/estadistica/estadisticade-biocarburantes (accessed on 23 September 2020).

75. Smeets, E.W.M.; Bouwman, A.F.; Stehfest, E.; van Vuuren, P.; Posthuma, A. Contribution of N2O to the greenhouse gas balance of first-generation biofuels. Glob. Chang. Biol. 2009, 15, 1-23. [CrossRef]

76. Prussi, M.; Yug, M.; Padella, M.; Edwards, R.; Lonza, L.; De Prada, L. JEC Well-to-Tank Report v5: Annexes Well-to-Wheels Analysis of Future Automotive Fuels and Powertrains in the European Context; Publications Office of the European Union: Luxembourg, 2020.

77. Prussi, M.; Yugo, M.; De Prada, L.; Padella, M.; Edwards, J.E.C. Well-To-Wheels Report v5; Publications Office of the European Union: Luxembourg, 2020. [CrossRef]

78. Wernet, G.; Steubing, B.; Reinhard, J.; Bauer, C.; Moreno-Ruiz, E. The ecoinvent database version 3 (part II): Analyzing LCA results and comparison to version 2. Int. J. Life Cycle Assess. 2016, 21, 1269-1281. [CrossRef]

79. Wernet, G.; Bauer, C.; Steubing, B.; Reinhard, J.; Moreno-Ruiz, E.; Weidema, B. The ecoinvent database version 3 (part I): Overview and methodology. Int. J. Life Cycle Assess. 2016, 21, 1218-1230. [CrossRef]

80. EMEP/EEA. 1.A.3.b.i-iv Road Transport 2019. In EMEP/EEA Air Pollutant Emission Inventory Guidebook 2019-Update Oct. 2020; European Enviroment Agency: Luxembourg, 2020; Volume 1, p. 1. ISBN 9788578110796. 
81. Lechón, Y.; Cabal, H.; de la Rúa, C.; Lago, C.; Izquierdo, L.; Sáez, R.M.; San Miguel, M.F. Análisis de Ciclo de Vida de Combustibles Alternativos para el Transporte. Fase II. Análisis de Ciclo de Vida Comparativo del Biodiésel y del Diésel; Centro de Publicaciones Secretaría General Técnica, Ministerio de Medio Ambiente: Madrid, Spain, 2006.

82. Lechón, Y.; Cabal, H.; de la Rúa, C.; Lago, C.; Izquierdo, L.; Sáez, R.M.; San Miguel, M.F. Análisis de Ciclo de Vida de Combustibles Alternativos para el Transporte. Fase I. Análisis de Ciclo de Vida comparativo del etanol de cereales y de la gasolina. Energía y cambio climático; Centro de Publicaciones Secretaría General Técnica, Ministerio de Medio Ambiente: Madrid, Spain, 2005; ISBN 84-8320-312-X.

83. European Commission. CASES (Cost Assessment of Sustainable Energy System), D.02.2-External Costs, Euro/ton Values; European Commision: Brussels, Belgium, 2008.

84. Thompson, T.M.; Saari, R.K.; Selin, N.E. Air quality resolution for health impact assessment: Influence of regional characteristics. Atmos. Chem. Phys. 2014, 14, 969-978. [CrossRef]

85. Gariazzo, C.; Carlino, G.; Silibello, C.; Tinarelli, G.; Renzi, M.; Finardi, S.; Pepe, N.; Barbero, D.; Radice, P.; Marinaccio, A.; et al. Impact of different exposure models and spatial resolution on the long-term effects of air pollution. Environ. Res. 2021, 192, 110351. [CrossRef]

86. de Ridder, K.; Viaene, P.; van de Vel, K. The impact of model resolution on simulated ambient air quality and associated human exposure. Atmósfera 2014, 27, 403-410. [CrossRef]

87. Paolella, D.A.; Tessum, C.W.; Adams, P.J.; Apte, J.S.; Chambliss, S.; Hill, J.; Muller, N.Z.; Marshall, J.D. Effect of Model Spatial Resolution on Estimates of Fine Particulate Matter Exposure and Exposure Disparities in the United States. Environ. Sci. Technol. Lett. 2018, 5, 436-441. [CrossRef]

88. Jiang, X.; Yoo, E.-h. The importance of spatial resolutions of Community Multiscale Air Quality (CMAQ) models on health impact assessment. Sci. Total Environ. 2018, 627, 1528-1543. [CrossRef] 